\title{
Does Services Liberalization Benefit Manufacturing Firms? Evidence from the Czech Republic
}

\author{
Jens Arnold* \\ Beata S. Javorcik ${ }^{* *}$ \\ Aaditya Mattoo ${ }^{* * *}$
}

\begin{abstract}
While there is considerable empirical evidence on the impact of liberalizing trade in goods, the effects of services liberalization have not been empirically established. Using firm-level data from the Czech Republic for the period 1998-2003, this study examines the link between services sector reforms and the productivity of domestic firms in downstream manufacturing. Several aspects of services liberalization are considered and measured, namely, the increased presence of foreign providers, privatization and enhanced competition. The manufacturing-services linkage is measured using information on the degree to which manufacturing firms rely on intermediate inputs from services industries. The econometric results lead to two conclusions: First, we find that services policy matters for the productivity of manufacturing firms relying on services inputs. This finding is robust to several econometric specifications, including controlling for unobservable firm heterogeneity and for other aspects of openness. Second, we find evidence that opening services sectors to foreign providers is a key channel through which services liberalization contributes to improved performance of downstream manufacturing sectors. This finding is robust to instrumenting for the extent of foreign presence in services industries. As most barriers to foreign investment today are not in goods but in services sectors, our findings may strengthen the argument for reform in this area.
\end{abstract}

Keywords: services liberalization, productivity, foreign direct investment JEL Codes: L8, F2, D24

World Bank Policy Research Working Paper 4109, January 2007

The Policy Research Working Paper Series disseminates the findings of work in progress to encourage the exchange of ideas about development issues. An objective of the series is to get the findings out quickly, even if the presentations are less than fully polished. The papers carry the names of the authors and should be cited accordingly. The findings, interpretations, and conclusions expressed in this paper are entirely those of the authors. They do not necessarily represent the view of the World Bank, its Executive Directors, or the countries they represent. Policy Research Working Papers are available online at http://econ.worldbank.org.

* OECD Economics Department, 2 rue André Pascal, 75116 Paris, France. Email: jens.arnold@oecd.org. ** World Bank and CEPR, 1818 H Street, NW; MSN MC3-303; Washington, DC, 20433. Email: bjavorcik@worldbank.org. *** World Bank, 1818 H Street, NW; MSN MC3-303; Washington, DC, 20433. Email: amattoo@worldbank.org. This paper is part of the World Bank's research program on trade in services, which is supported in part by the United Kingdom's Department for International Development. We thank Bruce Blonigen, Balázs Muraközy, Clinton Shiells and seminar participants at the World Bank, the European Bank for Reconstruction and Development, the London School of Economics, the Joint Vienna Institute, the University of Michigan, the George Washington University, the NBER Summer Institute 2006, the NBER Universities Research Conference, the Third CEPR Conference on "Trade, Industrialisation and Development" in Chianti, and the Empirical Investigations in International Economics Conference in Isola for helpful comments. 


\section{Introduction}

Services liberalization is a controversial subject, as is evident from recent policy debates in the European Union and the World Trade Organization. The scope for controversy is great because - in contrast to the large body of empirical research on the impact of trade liberalization in goods - little is known about the effects of allowing greater foreign entry in services industries. Since a wide range of manufacturing and services industries rely on services inputs, it seems reasonable to presume that large gains could be achieved through the liberalization of services sectors.

To the best of our knowledge, this is the first study which provides empirical evidence on the link between reforms in services sectors and the productivity of downstream manufacturing industries. ${ }^{2}$ Our analysis focuses on the Czech Republic which introduced far reaching reforms of services industries during the 1990s, including opening services sectors to foreign investors. The results, based on firm-level data for the period 1998-2003, suggest a positive association between liberalization in services industries and the productivity of manufacturing firms using services inputs.

Liberalization of services industries involves the abolition of monopolies, elimination of barriers to entry and the privatization of state-owned enterprises. As a result, new domestic and foreign providers are likely to enter the market and hence increase the choice of providers for downstream users of services. Greater choice of services providers may in turn affect the performance of manufacturing sectors in three ways.

First, the quality and reliability of existing services may improve as a result of privatization, competition and the entry of internationally successful players. For instance, telephone communications or electricity provision may become more reliable due to investments in infrastructure by new domestic owners or foreign shareholders, or credit decisions may be made faster as competition among banks increases. These improvements will in turn limit disruptions to production and reduce operating costs in downstream manufacturing sectors. ${ }^{3}$

Second, new services may become available through the entry of cutting-edge service providers. Examples include new financial instruments and cash flow management tools, multi-modal transport services, or digital value-added services in telecommunications. Availability of such services may allow manufacturers to introduce productivity enhancing changes to their operations, such as receiving production orders on line or setting up on-line bidding systems for suppliers.

Third, services liberalization may also lead to a wider availability of services that were formerly restricted to certain groups of users, such as internet coverage in rural areas or an improved availability of business consulting services to smaller firms. The improved access may lead to enhanced performance of smaller or remotely located enterprises.

The entry of foreign providers may play a particularly important role in realizing these benefits. Foreign providers may bring know-how and knowledge about new products and international best practices into the country. By setting a higher standard and introducing new products, they may also put pressure on domestic suppliers to make similar improvements. Given the limited scope for cross-border trade in services inputs, we would expect the performance of downstream sectors to be tied more directly to the quality and availability of services supplied by providers operating domestically than is the case for physical intermediate inputs.

\footnotetext{
${ }^{1}$ For instance, Pavcnik (2002) and Fernandes (2006) examine the implications of trade liberalization for the productivity of firms in protected sectors, while Amiti and Konings (2005) distinguish between the effects of lowering tariffs on final goods and lowering tariffs on intermediate inputs.

${ }^{2}$ The most closely related studies by Rajan and Zingales (1998) and Fernald (1999) are discussed in the next section. Recent efforts to estimate the economy-wide benefits of services reform using computable general equilibrium models (e.g. Rutherford, Tarr and Shepotylo 2005) assume downstream productivity effects of foreign entry into services markets, the existence of which the present paper is seeking to establish.

${ }^{3}$ In a case study of Mexican detergent industry, Javorcik, Keller and Tybout (2006) find that the entry of Wal-Mart reduced the distribution cost for detergent manufacturers. While in the past manufacturers used to deliver their products to individual supermarkets, Wal-Mart instituted a system of deliveries to a central warehouse which was later adopted by other supermarket chains. Moreover, the expansion of Wal-Mart into many regions of the country gave producers an opportunity to expand the reach of their products without having to engage in costly transactions with small wholesalers and retailers.
} 
The potential positive effect of liberalization and foreign presence in services sectors is reflected in the results of a firm survey conducted by the World Bank in the Czech Republic in 2004. A majority of the 350 Czech enterprises interviewed believed that liberalization of services industries contributed to improvements in the quality, range and availability of services inputs in their country.

A closer look at services industries in the Czech Republic reveals substantial differences between domestic and foreign-owned services providers. Foreign-owned providers exhibit higher labor productivity than their domestic counterparts and have a higher propensity to invest. The data also reveal an increase in productivity and investment taking place following the foreign acquisitions of Czech services firms. Moreover, the data show that after a foreign acquisition, target firms experience an increase in their market share, indicating a revealed consumer preference for the services provided by foreign-owned companies.

To examine the link between services sector reforms and the performance of services users, this study relates the total factor productivity of manufacturing firms to the state of liberalization in services sectors weighted by the respective manufacturing sector's reliance on inputs from each service sector. The analysis is based on firm level data from Amadeus, a commercial data base including financial statements and ownership information for approximately ten thousand Czech companies for the 1998-2003 period. The reliance of manufacturing sectors on services inputs is assessed based on the national input-output matrix.

Several measures are used to capture the extent of reform in services sectors. The first is a set of policy reform indices published by the European Bank for Reconstruction and Development (EBRD). Sectorspecific time-varying indices are available for banking, telecommunications, electric power, railway transport, road transport, and water distribution. The indices reflect the overall state of policy reform in a given services industry. Three additional measures capture a particular aspect of liberalization: (i) the extent to which foreign investors have entered Czech services industries, which is proxied by the share of an industry's output produced by foreign-owned companies; (ii) the progress of privatization in services industries, which is captured by the share of an industry's output produced by private companies; (iii) the level of competition in services industries, which is measured by the market share of the four largest providers.

In addition to proxies for services reform, the empirical analysis includes a comprehensive set of controls for other channels through which increased openness may affect firm performance. In particular, we control for the availability of material inputs provided by foreign-owned companies operating in upstream manufacturing sectors and for tariffs on imported intermediate inputs. To capture the level of competition in the output markets, we control for foreign presence and tariff protection in the same sector. The model includes firm fixed effects which control for unobserved firm heterogeneity and capture time-invariant effects specific to the industry and the region in which a firm operates. As a robustness check, we also estimate a model in first differences. To take into account the possible simultaneity between productivity shocks and input selection, we estimate the total factor productivity using the methodology proposed by Olley and Pakes (2003).

One final concern is the possible endogeneity of services liberalization. This concern is alleviated by the fact that services liberalization in the Czech Republic was undertaken in preparation for the country's accession to the European Union (EU) in May 2004, which lends considerable exogeneity to the pace of reforms and suggests that services liberalization and opening to foreign entry were exogenous developments rather than a response to domestic lobbying. Nevertheless, we demonstrate that our results are robust to using measures of services reforms lagged two periods. Moreover, taking advantage of the fact that neighboring countries, such as Slovakia and Hungary were also preparing for the EU accession, we use their progress in services reform to instrument for foreign presence in services industries in the Czech Republic and find that our conclusions remain unchanged.

Our main finding is a positive correlation between liberalization in services sectors and the productivity of manufacturing firms relying on services inputs. When each measure of reform is considered in isolation, a positive and statistically significant relationship is found for the overall progress in policy reform, the presence of foreign providers in services sectors and the extent of privatization in services industries. No 
statistically significant relationship is detected for the level of competition in services sectors. When multiple measures are entered jointly, the effect of privatization loses its statistical significance.

Our findings are consistent with services sector liberalization, particularly foreign direct investment (FDI) inflows into the sector, being associated with improved availability, range and quality of services, which in turn contribute to improved performance of manufacturing firms using services as inputs. The magnitude of the effect is economically meaningful: a one-standard-deviation increase in foreign presence in services industries is associated with a $3.8 \%$ increase in the productivity of manufacturing firms relying on services inputs.

Most of the barriers to foreign investment today are not in goods but in services (UNCTAD, 2004), reflecting the unwillingness of governments, particularly in developing countries, to allow unrestricted foreign presence in what they believe are "strategic" sectors. For example, even countries in South East Asia, such as Malaysia and Thailand, which have reaped huge benefits from the liberalization of trade and investment in goods continue to maintain restrictions on foreign ownership in services ranging from transport to telecommunications. India, which is emerging as a highly competitive supplier of a range of skilled labor-intensive services, still restricts foreign ownership in banking, insurance, telecommunications and retail distribution. Foreign entry into banking in Brazil and a number of other Latin American countries is subject to a high level of regulatory discretion, including in Brazil's case the need to obtain a Presidential decree. Our analysis suggests that these restrictions on foreign presence in producer services can seriously dampen the growth of productivity in manufacturing industries.

This paper is structured as follows. Section 2 reviews the relevant literature. Section 3 discusses the liberalization of services industries in the Czech Republic. Section 4 describes the data and the empirical strategy, while section 5 contains the empirical results. The last section presents the conclusion of the study.

\section{Related Literature}

As Hoekman (2006) notes, "research on services trade constitutes only a very small share of the total output of international economics" and "the share of rigorous empirical studies [on services] is particularly small, reflecting the scarcity of data on both policies and flows." The small existing literature encompasses a theoretical contribution by Francois (1990) who argues that the growth of intermediation services is an important determinant of overall economic growth and development and a handful of econometric studies based on aggregate data. Nicoletti and Scarpetta (2003) analyze multifactor productivity at the industry level, and find evidence of a positive link between entry liberalization in services sectors and productivity growth in manufacturing. Conway et al. (2006) use similar data, and document a faster catch-up of manufacturing productivity with respect to the leading country in those OECD countries that have more open services markets. Rajan and Zingales (1998) examine the impact of financial sector development on growth in downstream industries and find that more finance-dependent sectors grow faster in countries with well-developed financial markets. Fernald (1999) finds that changes in road growth are associated with larger changes in productivity growth in US industries that are more vehicle intensive. Hoekman and Eschenbach (2006) document a positive correlation between the extent of services liberalization and economic growth in transition countries during the 1990-2004 period. Mattoo, Rathindran and Subramanian (2006) present econometric evidence from a sample of 60 countries over the 1990-1999 period indicating that openness in the financial and telecommunications sectors influences long-run growth performance. ${ }^{4}$

The scarceness of evidence is particularly surprising considering the well-developed empirical literature on other channels through which openness may affect firm performance. The first channel, which has received

\footnotetext{
${ }^{4}$ A related literature considers the importance of services reform for goods trade. Francois and Wooton (2005) examine the interaction between competition in transportation and retail services, and trade in goods. They find that services liberalization can increase trade in goods, as long as it makes the market structure more competitive. Fink, Mattoo and Neagu (2005) show that communication costs affect the pattern of trade, and Freund and Weinhold (2002) find a trade-enhancing effect of internet connectivity.
} 
a lot of attention, is the effect of trade liberalization on indigenous producers in import-competing sectors and indigenous producers relying on imported inputs. In both cases, trade liberalization has been found to have a positive effect. For instance, Pavcnik (2002), who considers the Chilean trade liberalization, shows that plants in import-competing sectors grew by 3 to 10 percent more than those in sectors which were not exposed to foreign competition. Her findings suggest that Chilean plants had to improve their performance in response to exposure to competition from abroad. Fernandes (2006) demonstrates similar improvements in Colombia, as do Krishna and Mitra in India (1998), Muendler (2004) in Brazil and Goh and Javorcik (2006) in Poland. Analyzing the effects of trade liberalization in upstream manufacturing sectors, Amiti and Konings (2005) find a strong positive relationship between trade liberalization in intermediate inputs and firm productivity in downstream manufacturing sectors. Muendler (2004), however, concludes that this channel plays only a minor role.

The second channel, which has also been extensively investigated, is the impact of foreign direct investment on indigenous firms. A large number of studies consider the effect of foreign entry on indigenous producers operating in the same sector, postulating that foreign entry may result in knowledge spillovers to local firms (which would have a positive effect on the performance of the latter) as well as in local producers losing part of their market share to foreign entrants (which would have a negative effect as local producers would have to spread their fixed cost over a smaller scale of production). Empirical analyses based on firm-level panel data produce mixed results. Aitken and Harrison (1999), Djankov and Hoekman (2000), Konings (2001) and Javorcik (2004) find that the overall effect of these two forces is either negative or statistically insignificant, while Haskel, Pereira and Slaughter (2002) and Keller and Yeaple (2003) find a positive effect. More recently researchers have also analyzed inter-industry effects of foreign entry. Javorcik (2004) finds a positive effect of FDI on local producers in upstream industries and no significant effect on local producers in downstream manufacturing sectors in Lithuania. Kugler (2006) documents a positive effect of FDI inflows on Colombian producers in other sectors, i.e. sectors other than the sector receiving FDI. He considers the pairwise effects between sectors without distinguishing between the effects on downstream versus upstream sectors.

While the focus of this paper is on the relationship between services liberalization and the performance of domestic firms in downstream manufacturing sectors, we will also examine the impact of trade liberalization and foreign presence in both own and upstream manufacturing sectors. First, however, we turn to the developments in services sectors in the Czech Republic.

\section{Services Liberalization in the Czech Republic}

\subsection{Services Reform}

Having made substantial progress in liberalizing services sectors and opening its economy to foreign direct investment, the Czech Republic is a suitable choice for our study. Within a few years after the end of the communist regime in 1989, the government of the former Czechoslovakia privatized many state-owned enterprises, liberalized prices and wage-setting and began to open the country to foreign trade and FDI (Hanousek, Kocenda and Lizal 2004). In 1998, Czech policy makers adopted an even more welcoming approach to foreign direct investment, particularly in services industries, and FDI inflows saw a steep rise. A summary of the reform measures undertaken in the banking, telecommunications and energy sectors is presented here, while Appendix A contains a more detailed description.

In the telecommunications sector, the monopoly fixed line operator was majority public-owned in 1998, and there was no independent regulator for the sector. In early 2000, the Telecommunications Act established an independent regulator and determined that the fixed line monopoly of the incumbent would end on January 1, 2001. Yet, as interconnection prices remained above comparable prices in the European Union and certain other reform-related issues had not been addressed, the EU called for immediate remedial action. A third mobile operator entered the market in 2000 with $100 \%$ foreign ownership, and in 2001 the foreign private investor in one of the two mobile companies operating since 1996 increased its shares to $60 \%$. In August 2002, the government decided to privatize the state's majority stake in the incumbent fixed line operator. Now there is a choice of operators in all segments of the market, and 
according to WTO (2001) there has been "strong growth in both size and quality of services, and prices of some services have fallen."

In the banking sector, the privatization of the four large state-controlled banks began in March 1998 . Foreign investors were given national treatment as of 1998, and the supervisory powers of the central bank were strengthened. In 1999, the government published a precise and ambitious timetable for the remaining privatizations in banking and by $200190 \%$ of banking assets were in foreign-controlled banks, with 27 out of 40 commercial banks being foreign owned. In 2002, after another legal reform, the EU deemed the banking sector in the Czech Republic to be in compliance with the Acquis Communautaire.

In the energy sector, a regulatory administration was established in 1998, although its independence was still limited. On 1 January 2001, a new Energy Act came into force providing for a gradual liberalization of the electricity and gas markets, including third party access starting in 2002. The privatization of the Czech monopoly gas importer and owner of the transit network, together with shares giving majority stakes in seven out of eight regional gas monopoly distributors, was concluded in May 2002. In 2002, the European Commission found the Czech gas and electricity sectors to be well prepared for the competitive EU-internal energy market thanks to the privatization of major players in the gas market, the restructuring of electricity utilities and broadly cost-reflective electricity prices.

In response to changes in the policy environment, the Czech Republic has received large inflows of FDI into services sectors. The aggregate FDI inflows (encompassing both services and other sectors) in 1998 were twice as large as in the preceding year and doubled again in 1999. In fact, the Czech Republic is one of the most successful Central and Eastern European countries in terms of the stock of foreign direct investment per capita. Many of the world's most prominent multinational companies have established themselves in the Czech market. As demonstrated in Figure 1, a majority of recent FDI inflows into the Czech Republic have been directed into services rather than manufacturing sectors. Almost all services industries have attracted foreign investors (see Figure 2 which depicts the distribution of FDI inflows across services industries during the period considered in our study, 1998-2003).

The progress of the liberalization of the Czech economy with respect to both domestic regulation and openness to foreign entry was closely monitored by the European Union in preparation for the country's accession in $2004 .^{5}$ The fact that a substantial liberalization of services was required to attain one of the country's major policy goals lends considerable exogeneity to the pace of reform and suggests that services liberalization and openness to foreign entry were exogenous developments rather than a response to domestic lobbying.

\subsection{Anecdotal Evidence on the Effects of Services Reform}

There is considerable anecdotal evidence suggesting that quality improvements and the introduction of new services in the Czech Republic have been related to the liberalization of services industries and the presence of foreign providers. For example, the Czech Republic was lagging behind all its Western European neighbors with respect to the use of cellular phones in 1998, which is the first year considered in our analysis. By 2003, however, it was second only to Italy and Sweden with respect to the number of cell phones per 100 inhabitants (see Figure 3). Similarly, with respect to the number of internet users per 100 inhabitants, the country advanced from being at the bottom of the ranking in 1998 to a middle position in 2003, leaving behind countries such as Greece, Spain and Portugal and reaching the levels of Ireland and Italy. It is also suggestive that in countries such as Bulgaria, Russia, Romania and Ukraine, where little progress was made with respect to services reform, internet usage remains at the level of 0.05 to 0.15 internet users per 100 people, which is an order of magnitude lower than the corresponding figure for the Czech Republic.

Banking is another example of a sector where foreign firms have been at the forefront of introducing innovative services in the Czech market. Ceska Sporitelna, a large Austrian-owned bank, installed 1,080

5 The European Commission published extensive yearly reports on "Progress towards Accession" on its website at http://europa.eu.int/comm/enlargement. 
ATMs across the country and issued 2.7 million payment cards by early 2005 . It was also the first bank to offer transaction ATMs, at which customers could pay their bills or make transfers. Moreover, it has become the market leader in remote banking, offering services via phone, cell phone or internet. When Ceska Sporitelna introduced a new internet banking service in 2002, 70,000 Czech customers signed up for the new service during the first 2 months. By now, the service has about 800,000 users.

Foreign banks were also the first to speed up processing of loan applications. For instance, at the US-owned GE Capital Bank, decisions about loans to small and medium enterprises are made within 2 days. Ceska Sporitelna guarantees the issuance of any debit card within 6 days from the filing of the application. HVB Bank, another foreign-owned bank, offers its corporate clients a software package that allows internet banking with multiple banks, domestic and international transactions, and multiple approval procedures of transactions within the company via electronic signatures, even if one of the approvers is located abroad. These changes suggest that opening services sectors to foreign entry have significantly changed the nature of the services sectors in the Czech Republic.

\subsection{Firms' Perceptions of the Effects of Services Reform}

Consistent with the anecdotal evidence, Czech managers exhibit very positive views of services sector reforms in their country. In 2004, the World Bank surveyed 350 Czech firms about their perceptions regarding different aspects of the services reform. Managers were asked whether they felt that the changes had a positive or a negative impact on their firms with regard to quality, prices, the range of services on offer and the availability of these services. As illustrated in Figure 4, the results of the survey portrayed a generally positive view of services reform. The share of positive perceptions ranged from $55 \%$ of the respondents when asked about the quality of accounting and auditing services to $82 \%$ for telecommunications. With regards to the variety of products offered, the positive views of liberalization varied between $56 \%$ of respondents evaluating accounting and auditing services to $87 \%$ of respondents asked about telecommunications. The corresponding figures for the effect on services availability ranged from $47 \%$ in accounting and auditing to $80 \%$ in telecommunications. ${ }^{6}$

\subsection{Evidence of the Superior Performance of Foreign Services Providers}

To shed more light on developments in services industries we take a closer look at services providers and explore the extent to which there exist systematic differences between domestic and foreign-owned firms with respect to a number of performance indicators between 1998 and 2003 . We do so by estimating a simple model

$$
Y_{i t}=\alpha+\beta \cdot \text { foreign }_{i t}+\gamma \cdot \text { size }_{i}+D_{j} \cdot \kappa+D_{t} \cdot \theta+D_{\text {reg }} \cdot \mu+\varepsilon_{i t}
$$

where foreign $_{i t}$ is a dummy variable taking on the value of one if the foreign ownership share in firm $i$ at time $t$ exceeded $10 \%$ and zero otherwise, size $e_{i}$ captures the initial size of each company as measured by the logarithm of employment in 1998, the initial year of the sample, and $D_{j}, D_{t}$ and $D_{\text {reg }}$ are fixed effects for industries, years and regions. The model is estimated on services industries.

TABLE 1. Performance premiums of foreign services firms and foreign acquisition targets

\begin{tabular}{ll|c|c|cc}
\hline & & $\begin{array}{c}\text { Foreign } \\
\text { Premium }\end{array}$ & $\begin{array}{c}\text { Post-Acq. } \\
\text { Premium }\end{array}$ & $\begin{array}{c}\text { Pre- and Post- } \\
\text { Acq. } \\
\text { Premium }\end{array}$ & $\begin{array}{c}\text { Difference Test } \\
\text { Pre/Post Acq. }\end{array}$ \\
\hline \hline \begin{tabular}{ll|cl} 
Labor Productivity \\
(Log Val Add p.w.)
\end{tabular} & Foreign Premium & $0.758^{* * *}$ & $1.011^{* * *}$ & $1.078^{* * *}$ & \\
\hline Log Investment & Pre-Acq. Period & & & $0.621^{* * *}$ & $\mathrm{~F}=4.91^{* *}$ \\
(Capital Growth) & Pre-Acq. Period & $1.004^{* * *}$ & $0.843^{* * *}$ & $0.880^{* * *}$ & \\
\hline Market Share & Premium & $0.013^{* * *}$ & $0.016^{* * *}$ & $0.017^{* * *}$ & \\
& Pre-Acq. Period & & & $0.009^{* * *}$ & $\mathrm{~F}=14.34^{* * *}$ \\
\hline
\end{tabular}

\footnotetext{
${ }^{6}$ For exact wording of the survey questions, see Appendix B.
} 


\begin{tabular}{l|c|c|c}
\hline Initial Size & Yes & Yes & Yes \\
Industry FE & Yes & Yes & Yes \\
Region FE & Yes & Yes & Yes \\
Year FE & Yes & Yes & Yes \\
Sample & All services & Excluding & Excluding \\
& firms & always & always \\
foreign firms & foreign firms \\
\hline \hline
\end{tabular}

The premiums are estimated coefficients on a binary variable for foreign ownership or post-acquisition years in the case of firms that were acquired by foreigners. The pre-acquisition period of future acquisition targets is also captured by a dummy variable, and the last column tests for equality of the coefficients on the pre- and post-acquisition dummies. Initial size is controlled by the log of employees in 1998 . All regressions control for industry, region and year fixed effects. The number of observations in these regressions ranges from 5096 for labor productivity (due to missing values in employment) and 8092 for market share.

The source of firm-level information is the Amadeus data base published by Bureau van Dijk. It contains annual balance sheets and income statements of firms operating in the Czech Republic. The data base includes all firms that either had total assets of more than 20 million Czech Crowns (CZK) or a turnover of more than 40 million CZK. The firm records contain information on volume of sales, labor and intermediate inputs, stock of tangible fixed assets, and ownership structure. To obtain the largest possible sample, we use information from several releases of the Amadeus data base and focus on the period 19982003. ${ }^{7}$ Nominal values of output are deflated using wholesale deflators specific to 3-digit NACE sectors, obtained from the Czech Statistical Office (CSO). For capital, a deflator for tangible fixed assets, obtained from the $\mathrm{CSO}$, is used.

The results, presented in table 1, suggest that there exist significant differences between domestic and foreign-owned firms operating in services industries. Foreign-owned services firms have a significantly higher labor productivity, investment outlays and market shares. Although these results demonstrate systematic differences related to ownership, they cannot be interpreted as evidence of a causal relationship. While a careful analysis of the direction of causality is beyond the scope of this paper, we can go a step further and exploit the within-firm ownership changes due to 280 foreign acquisitions that we observe in services industries in our data set. ${ }^{8}$ If the performance differences are related to ownership differences per se, we would expect to observe changes in these variables in firms changing their ownership status from domestic to foreign. Thus, in the second column of table 1, we exclude firms under foreign ownership throughout the period and let the foreign ownership indicator capture post-acquisition periods of the acquired firms. As before, we find that firms under foreign ownership exhibit positive and statistically significant performance premiums. In the models presented in the third column of table 1, we include two indicator variables: a dummy for the acquired firms observed one year before the ownership change and a dummy for the acquired firms observed after the ownership change. The coefficients on both variables are positive and statistically significant which suggests that firms changing ownership exhibit superior performance before as well as after being acquired, with the latter premium being larger. The difference between the two coefficients is statistically significant and thus presents further evidence in favor of positive performance effects associated with foreign ownership. The fact that firms increase their market share after being acquired by foreign capital is also an indication that services users value performance differences associated with foreign ownership.

\footnotetext{
${ }^{7}$ As happens with most large firm-level data sets, Amadeus contains cases of obvious key punch errors. In many of these cases, we are able to obtain the correct information from account statements on the company websites. In the remaining cases, we apply rules to identify and remove probable data errors from our sample, as outlined in Appendix C.

${ }^{8}$ For a more complete econometric analysis of the causal relationship between foreign ownership and firm performance in manufacturing sectors in Indonesia, see Arnold and Javorcik (2005).
} 
In summary, the anecdotal and the survey evidence as well as the econometric results demonstrating superior performance of foreign services providers suggest that service sector reform, and particularly foreign presence in these sectors, has left a positive mark on these industries. In the next section, we explore the implications of these changes for the manufacturing industries that rely on services inputs, which is the main objective of our analysis.

\section{Empirical Strategy}

Our firm-level data include information on firms in 21 manufacturing industries. ${ }^{9}$ As our measure of firm performance, we estimate the total factor productivity (TFP) for all manufacturing firms. The TFP is estimated as the residual of a three-factor Cobb-Douglas production function, with deflated values of labor, capital and material/services inputs as production factors. Nominal values of output are deflated using wholesale deflators specific to 3-digit NACE sectors, obtained from the Czech Statistical Office (CSO). Labor costs are deflated using the consumer price index from IMF's International Financial Statistics. For capital, a deflator for tangible fixed assets, obtained from the CSO, is used.

As our objective is to assess the effect of services liberalization on firm performance, it is important to properly account for the usage of services inputs. While services inputs are not directly reported in the Amadeus data base, consultations with foreign accounting firms operating in the Czech Republic suggested that the data on the (combined) use of services and material inputs could be obtained by subtracting value added and extraordinary profit/loss ${ }^{10}$ from the operating revenue. All three variables are reported in the Amadeus data base. In accounting terms, the material and services usage derived in this way is equal to the sum of (i) the cost of goods sold excluding wages, (ii) other operating expenses excluding depreciation, ${ }^{11}$ and (iii) financial costs less financial revenues, excluding interest payments. ${ }^{12}$ The value of material and services inputs is deflated using wholesale deflators specific to 2-digit NACE sectors (both manufacturing and services industries) weighted by the share of each sector in the provision of inputs taken from the input-output matrix. The use of this composite deflator gives us some confidence that we are taking into account changes in prices of services inputs. ${ }^{13}$

We estimate the production function separately for 14 manufacturing sectors, using both ordinary least squares (OLS) and the semi-parametric estimation technique suggested by Olley and Pakes (1996). ${ }^{14}$ The latter technique controls for a possible simultaneity bias arising from the endogeneity of a firm's input selection, which will exist if a firm responds to productivity shocks unobservable to the econometrician by adjusting its input choices. Such behavior would lead to correlation between an explanatory variable and the error term in the estimation of the production function, thus violating one of the basic requirements for the validity of the OLS estimation. The Olley and Pakes estimator corrects for the possible bias that may result from this correlation by using the firm's investment decision as a proxy for unobserved productivity shocks. ${ }^{15}$ The estimated TFP is then related to the extent of liberalization in services industries. ${ }^{16}$

Liberalization of services industries is measured in several ways. The first measure comes from the European Bank for Reconstruction and Development publication Transition Report 2004. The EBRD publishes indices of policy reform for banking, telecommunications, electric power, railway transport, road transport, and water distribution as well as an overall index for services sectors. We use the overall index

\footnotetext{
${ }^{9}$ The petroleum sector (NACE 23) was excluded from the analysis because of a very small number of observations.

${ }^{10}$ Extraordinary profit/loss pertains to items related to natural disasters and insurance claims.

${ }^{11}$ Other operating expenses include insurance costs, depreciation, donations and penalties.

${ }^{12}$ Financial costs include bank fees, interest paid and costs related exchange rate differences.

${ }^{13}$ If changes in services prices do not fully reflect the improvements in services quality, these improvements will be captured by the total factor productivity. If they are a result of services liberalization, then they are part of the effect we intend to capture.

${ }^{14}$ We group similar 2-digit sectors together to get a larger number of observations. See Appendix D for a list of groupings.

${ }^{15}$ Details of the procedure are outlined in Olley and Pakes (1996), as well as in other papers that applied the procedure in the context of international trade and investment, such as Pavcnik (2002), Javorcik (2004) and Arnold and Hussinger (2005). The coefficients from the estimated production functions are presented in Appendix D.

${ }^{16}$ Note that in Appendix E we demonstrate that our results are robust to using a one-stage approach, i.e. including variables of interest in the production function.
} 
for those services industries where sector-specific information is not available. All of the indices are available for 1998-2002. According to the EBRD, the scores "reflect the judgment of the EBRD's Office of the Chief Economist about country-specific progress in transition." The advantage of using these measures is that they are in principle designed to encompass all policy aspects of liberalization, both with respect to domestic and foreign providers. ${ }^{17}$ However, this broad coverage comes at the cost of a limited precision, particularly with respect to the time variation of the indicators.

Therefore, we employ alternative measures aiming to capture particular aspects of services reform, namely (i) the extent to which foreign investors have entered Czech services industries; (ii) the progress of privatization in services industries; and (iii) the level of competition in services industries. These proxies offer several advantages. First, they can be measured precisely. Second, allowing foreign entry or privatizing state owned enterprises is a good indicator of a serious commitment to reform. Third, all these measures are outcomes rather than policy variables, which means that they encompass implementation as well as policies. Fourth, comparing the results for individual measures can offer insights into the relative importance of various aspects of services liberalization.

The extent of foreign presence in services sectors is measured by the share of foreign-owned providers in sectoral sales. Firm-level ownership information is available in Amadeus in the form of records on shareholders, their nationalities and their ownership shares, including the dates as of which the information is valid. The date records pertain to the latest available information in each release of Amadeus, i.e. they are not time-varying within one version of the data base. Therefore, we combine the information from four different releases of Amadeus (1998, October 2001, January 2005 and March 2005) and construct a panel of foreign ownership shares for each firm. ${ }^{18}$ In cases where the date of foreign entry was ambiguous, we looked up information on the owners from other publicly available sources. This usually allowed us to eliminate any residual doubts. For the top 5 companies in each sector and year, we additionally verified any available information about foreign owners and their date of entry by looking at annual reports and information on the company websites.

Throughout the paper, we employ two definitions of foreign ownership shares: a threshold definition and a capital share definition. In the former, a firm's entire output is counted as foreign if the sum of the shares held by foreign entities exceeds $10 \%$ (the standard threshold for defining FDI). In the latter, a firm's output is weighted by the foreign ownership share and only this fraction is considered as foreign output. Using these two definitions, we calculate the share of foreign output at the level of 2-digit services sectors of the NACE classification for the years 1998 to 2002. In what follows, we will refer to the foreign output share variables as foreign share.

We construct the foreign share variables for the following services sectors: other business activities (includes legal, accounting, consulting, advertising services) (NACE code 74), computer and related activities (72), renting of machinery and equipment (71), real estate activities (70), financial intermediation (65), post and telecommunications (64), supporting and auxiliary transport activities (63), land transport (60), retail trade and repair of personal and household goods (52), wholesale trade and commission trade (51), sale, maintenance and repair of motor vehicles and retail sale of automotive fuel (50), construction (45), collection, purification and distribution of water (41), electricity, gas and hot water supply (40). ${ }^{19}$ Foreign engagement in these sectors varies substantially. While in the electricity sector almost $76 \%$ of sales in 2002 came from firms with at least $10 \%$ foreign ownership, this ratio reached only $8 \%$ in land transport. There is also a significant variation across time. The average of foreign output shares more than doubled between 1998 and 2002.

The progress of privatization in services industries is measured by the share of output provided by firms with private owners. The determination of whether a particular owner is a private entity or a state or

\footnotetext{
${ }^{17}$ The indices are described in more detail in Appendix F.

${ }^{18}$ Note that in contrast to other releases, the January 2005 release contained ownership information relating to earlier dates which proved invaluable in constructing ownership changes taking place during the 2002-04 period.

${ }^{19}$ The following services sector had to be excluded due to a small number of observations in the data: hotels and restaurants (55), water transport (61), air transport (62), insurance and pension funding (66), activities auxiliary to financial intermediation (67).
} 
municipal government or agency is made based on the shareholder name and description in the Amadeus data base. As in the case of foreign ownership, we employ both a threshold and a capital share definition.

The level of competition in each services industry is proxied by two indices of concentration: the market share of the four largest providers and the Herfindahl index which is defined as the sum of squared market shares of all providers in the sector. As our results show no qualitative difference between the findings based on the two indices, we present the estimation results only for the former index.

Since we are interested in inter-sectoral linkages between services and manufacturing industries, we need to weigh the extent of liberalization in each services sector by the reliance of manufacturing firms on each services input. While we do not have information on services inputs at the level of individual firms, we can use information from a national input-output matrix to evaluate inter-industry dependencies between individual manufacturing and services sectors. ${ }^{20}$ An advantage of using the industry level information is that there is less need to be concerned about a correlation between the performance of an individual firm and its services usage. Based on the information on the relative importance of each services sector for manufacturing industries, we calculate the following measures for each manufacturing industry $j$ at time $t$ :

services_linkage $_{j t}=\sum_{k} a_{j k} \cdot$ liberalization_index ${ }_{k t}$

where $a_{j k}$ is the amount of inputs sourced from services sector $k$, expressed as a fraction of the overall inputs used by manufacturing sector $j$. Liberalization_index $x_{k t}$ is one of the six measures discussed above: the EBRD index of reform in services sector $k$ at time $t$, foreign share ${ }_{k t}$ defined based on capital shares or thresholds for services sector $k$ at time $t$, the share of output provided by private companies in services sector $k$ at time $t$ (defined based on capital shares or thresholds) or the concentration index for services sector $k$ at time $t$. Put differently, the services_linkage variable is obtained by multiplying the matrix of sectoral reform indicators for services sectors with a matrix of input-output coefficients. ${ }^{21}$

To establish whether there exists a link between the performance of Czech firms and liberalization of upstream services sectors, we regress the productivity of manufacturing firms on the services_linkage measures:

$\mathrm{TFP}_{i t}=\alpha+\beta \cdot$ services_linkage $_{j t-1}+X_{j t-1} \cdot \gamma+D_{i} \cdot \delta+\eta_{i t}$

where $T F P_{i t}$ is the total factor productivity of a Czech manufacturing firm $i$ operating at time $t$ estimated at the industry level using alternatively ordinary least squares or the semiparametric Olley and Pakes method and $X_{j t-1}$ is a vector of controls for other aspects of the increasing integration of the Czech economy with the outside world. As the effects of services liberalization and other aspects of international integration may take time to materialize, these variables are lagged one period.

There are two advantages of using firm-level rather than industry-level data. First, we can include firm fixed effects $\left(D_{i}\right)$ to capture unobserved firm heterogeneity related to firm location, size, the subindustry of operation, manager's characteristics, age, etc. Second, firm-level data allow us to isolate the effect on domestic firms, which is the policy outcome likely to be of highest interest to national policy makers. For this reason, only firms in manufacturing sectors (NACE Codes 15 to 36) that have less than $10 \%$ of foreign ownership at all times are considered in the regressions. ${ }^{22}$

The vector $X_{j t-1}$ controls for other aspects of openness not related to services liberalization. In particular, it includes a sector-specific measure of foreign presence in upstream manufacturing sectors, constructed in

\footnotetext{
${ }^{20}$ We employ the use table of the input-output matrix for the year 2000, obtained from the CSO. Ideally, we would want to have annual information, but unfortunately it is not available. Note, however, that the year 2000 lies approximately in the middle of the time period covered by our sample.

${ }^{21}$ This way of measuring cross-sector effects was used by, for instance, Javorcik (2004).

${ }^{22}$ Note that including foreign firms in the sample leads to very similar results. It could be of interest whether foreign manufacturers located in the Czech Republic benefit more or less from services reform than Czech manufacturers. But rigorously examining the effect on foreign firms would require dealing with the possible endogeneity of foreign ownership which is beyond the scope of this paper.
} 
the same way as the services_linkage variables. Foreign entry into manufacturing industries may affect the sourcing options for manufacturing inputs by increasing the quality and range of products available. To account for the sourcing options offered by imported inputs, $X_{j t-1}$ also includes the level of tariff protection in upstream manufacturing sectors, again weighted by the input-output coefficients. Our tariff measures are applied MFN tariffs. In preparation for accession to the European Union, Czech tariffs vis-à-vis the EU were governed by a bilateral accession agreement of 1992, which established a schedule for phasing out tariffs on most manufacturing products by the end of 2000. In practice, this means that for the time frame we are investigating, EU preferential tariffs outside the food and tobacco sectors were already very low, with an average tariff of less than half a percent. In the presence of virtual free trade with the EU, it does not seem sensible to exploit the minimal variation in this protection before 2001, and indeed our data show little evidence that this aspect of trade protection matters. Instead we focus on MFN tariffs, which will capture protection vis-à-vis imports from non-EU countries, such as the United States and China. In Appendix G, however, we repeat some of our basic regressions including both EU preferential and MFN tariff rates and show that the results are robust to this change.

Finally, to control for the level of competition and possible knowledge spillovers, we also include measures of foreign entry into a firm's own sector as well as the level of tariff protection in the same sector. ${ }^{23}$ To take into account other factors that may generate a correlation between the performance of manufacturing firms and foreign entry into services sectors, such as regional differences in remoteness or quality of infrastructure, or events that improve business prospects in both services and manufacturing in a specific year, we include firm and year fixed effects. The firm fixed effects will also control for unobserved heterogeneity of firms.

In our second specification, we estimate the model in first differences rather than in levels. Differencing takes out all observable and unobservable time-invariant characteristics at the level of the firm as well as at the level of the industry and region. By including region and year fixed effects in the model in first differences, we additionally control for differences in trends (rather than in levels) that are specific to a particular region or for factors affecting the whole economy in a particular period. For example, differences in regional public spending on infrastructure or economy wide shocks would be picked up by these fixed effects in the differenced equation and would not bias our coefficient estimate of the services linkage variable. Our second specification takes the following form:

$$
\Delta T F P_{i t}=v+\phi \cdot \Delta \text { services_linkage }{ }_{j t-1}+\Delta X_{j t-1} \cdot \varphi+D_{t} \cdot \theta+D_{\text {reg }} \cdot \mu+\omega_{i t}
$$

As the variables of interest are at the industry level while the dependent variable is at the firm-level, we adjust standard errors to allow for correlation between observations belonging to the same industry in the same year. The summary statistics for all variables are presented in Appendix $\mathrm{H}$.

\section{Results}

The results from the estimation of equation 3 based on OLS productivity estimates are shown in table 2 . When we enter the measures of services_linkages into the model one by one, we find a positive and statistically significant correlation between firm performance in downstream manufacturing and the overall liberalization of services (EBRD measure, column I), the presence of foreign providers of services (measured using the two alternative definitions of foreign output in columns II and III) and the extent of privatization in services industries (but only when the capital share definition is used in column V). The effects are statistically significant at the one or at the five percent level. These results support our hypothesis that services liberalization affects the performance of domestic manufacturing firms relying on services inputs. The extent of competition in services, proxied by the concentration ratio (or the Herfindahl index, not reported to save space), does not appear to have a statistically significant effect. When the three aspects of services reform (foreign presence, privatization and competition) enter the model jointly in columns VII and VIII, only the presence of foreign providers is statistically significant. This suggests that

${ }^{23} \mathrm{We}$ have also experimented with concentration measures in the same sector, but these turned out to have no systematic significant effect. 
allowing foreign entry into services industries may be the key channel through which services liberalization contributes to improved performance of downstream manufacturing sectors.

TABLE 2. Estimation with firm fixed effects using OLS productivities:

Productivity in domestic manufacturing firms and reform in upstream services sectors

\begin{tabular}{|c|c|c|c|c|c|c|c|c|c|}
\hline \multicolumn{2}{|c|}{ Dependent Variable: $\ln (\mathrm{TFP})$} & \multirow{3}{*}{$\begin{array}{c}\mathrm{I} \\
1.003 * * \\
(0.399)\end{array}$} & \multirow[t]{2}{*}{ II } & \multirow[t]{2}{*}{ III } & \multirow[t]{2}{*}{ IV } & \multirow[t]{2}{*}{$\mathrm{V}$} & \multirow[t]{2}{*}{ VI } & \multirow[t]{2}{*}{ VII } & \multirow[t]{2}{*}{ VIII } \\
\hline Services input & EBRD & & & & & & & & \\
\hline \multirow[t]{11}{*}{ linkages } & & & & & & & & & \\
\hline & FDI (share) & & $6.220 * * *$ & & & & & $5.661 * *$ & \\
\hline & & & $(1.934)$ & & & & & $(2.316)$ & \\
\hline & & & & $2.472 * *$ & & & & & $2.665 * * *$ \\
\hline & FDI (threshold) & & & $(0.967)$ & & & & & $(0.962)$ \\
\hline & Concentration & & & & 0.983 & & & 2.919 & 1.166 \\
\hline & & & & & $(2.876)$ & & & $(2.732)$ & $(2.707)$ \\
\hline & Privatization & & & & & $10.087 * *$ & & 5.398 & \\
\hline & (share) & & & & & $(4.856)$ & & $(5.819)$ & \\
\hline & Privatization & & & & & & -24.591 & & -27.388 \\
\hline & (threshold) & & & & & & $(19.823)$ & & $(19.101)$ \\
\hline \multirow{6}{*}{$\begin{array}{l}\text { Manufacturing } \\
\text { input linkages }\end{array}$} & FDI (share) & & -0.332 & & & $-0.720 *$ & & -0.458 & \\
\hline & & & $(0.461)$ & & & $(0.419)$ & & $(0.487)$ & \\
\hline & & -0.341 & & -0.366 & -0.582 & & -0.528 & & -0.393 \\
\hline & FDI (threshold) & $(0.391)$ & & $(0.383)$ & $(0.393)$ & & $(0.391)$ & & $(0.403)$ \\
\hline & MFN Tariff & -0.184 & $-0.368 * * *$ & $-0.258 * *$ & -0.075 & $-0.183^{*}$ & -0.079 & $-0.377 * * *$ & $-0.272 * *$ \\
\hline & & $(0.112)$ & $(0.130)$ & $(0.126)$ & $(0.109)$ & $(0.107)$ & $(0.105)$ & $(0.134)$ & $(0.124)$ \\
\hline \multirow{8}{*}{$\begin{array}{l}\text { Within sector } \\
\text { effects }\end{array}$} & FDI (share) & & 0.076 & & & $0.326^{*}$ & & 0.154 & \\
\hline & & & $(0.192)$ & & & $(0.182)$ & & $(0.207)$ & \\
\hline & & 0.22 & & 0.198 & $0.378 * *$ & & $0.344 * *$ & & 0.207 \\
\hline & FDI (threshold) & $(0.150)$ & & $(0.148)$ & $(0.169)$ & & $(0.153)$ & & $(0.166)$ \\
\hline & MFN Tariff & $0.105^{*}$ & $0.190 * * *$ & $0.136^{* *}$ & 0.056 & $0.097 *$ & 0.055 & $0.193 * * *$ & $0.143 * *$ \\
\hline & & $(0.056)$ & $(0.064)$ & $(0.062)$ & $(0.055)$ & $(0.055)$ & $(0.053)$ & $(0.067)$ & $(0.060)$ \\
\hline & No. of obs. & 7155 & 7155 & 7155 & 7155 & 7155 & 7155 & 7155 & 7155 \\
\hline & $\mathrm{R}^{2}$ & 0.095 & 0.095 & 0.095 & 0.094 & 0.094 & 0.094 & 0.095 & 0.095 \\
\hline
\end{tabular}

errors clustered on industry-year combinations are presented in parentheses. *, $* *, * * *$ indicate statistical significance at the 10,5 and $1 \%$ level.

TABLE 3. Estimation with firm fixed effects using Olley-Pakes productivities:

Productivity in domestic manufacturing firms and reform in upstream services sectors

\begin{tabular}{|c|c|c|c|c|c|c|c|c|c|}
\hline \multicolumn{2}{|c|}{ Dependent Variable: $\ln (\mathrm{TFP})$} & \multirow{3}{*}{$\begin{array}{c}\mathrm{I} \\
0.891 * * \\
(0.404)\end{array}$} & \multirow[t]{2}{*}{ II } & \multirow[t]{2}{*}{ III } & \multirow[t]{2}{*}{ IV } & \multirow[t]{2}{*}{$\mathrm{V}$} & \multirow[t]{2}{*}{ VI } & \multirow[t]{2}{*}{ VII } & \multirow[t]{2}{*}{ VIII } \\
\hline Services input & EBRD & & & & & & & & \\
\hline \multirow[t]{9}{*}{ linkages } & & & & & & & & & \\
\hline & FDI (share) & & $5.844 * * *$ & & & & & $4.732 *$ & \\
\hline & & & $(1.979)$ & & & & & $(2.471)$ & \\
\hline & & & & $2.090 * *$ & & & & & $2.241 * *$ \\
\hline & FDI (threshold) & & & $(1.012)$ & & & & & (1.013) \\
\hline & Concentration & & & & 2.146 & & & 4.164 & 2.37 \\
\hline & & & & & $(2.939)$ & & & $(2.957)$ & $(2.812)$ \\
\hline & Privatization & & & & & $12.392 * * *$ & & 9.332 & \\
\hline & (share) & & & & & (4.581) & & (5.933) & \\
\hline
\end{tabular}




\begin{tabular}{|c|c|c|c|c|c|c|c|c|c|}
\hline & $\begin{array}{l}\text { Privatization } \\
\text { (threshold) }\end{array}$ & & & & & & $\begin{array}{l}-14.396 \\
(18.941)\end{array}$ & & $\begin{array}{l}-16.411 \\
(18.299)\end{array}$ \\
\hline \multirow{6}{*}{$\begin{array}{l}\text { Manufacturing } \\
\text { input linkages }\end{array}$} & FDI (share) & & -0.038 & & & -0.34 & & -0.213 & \\
\hline & & & $(0.489)$ & & & $(0.439)$ & & $(0.509)$ & \\
\hline & & -0.153 & & -0.183 & -0.424 & & -0.323 & & -0.272 \\
\hline & FDI (threshold) & $(0.428)$ & & $(0.415)$ & $(0.420)$ & & $(0.418)$ & & $(0.432)$ \\
\hline & MFN Tariff & -0.136 & $-0.307 * *$ & -0.194 & -0.037 & -0.147 & -0.042 & $-0.316^{* *}$ & -0.201 \\
\hline & & $(0.107)$ & $(0.130)$ & $(0.124)$ & $(0.103)$ & $(0.104)$ & $(0.100)$ & $(0.133)$ & $(0.124)$ \\
\hline \multirow{8}{*}{$\begin{array}{l}\text { Within sector } \\
\text { effects }\end{array}$} & FDI (share) & & -0.084 & & & 0.131 & & 0.033 & \\
\hline & & & $(0.202)$ & & & $(0.189)$ & & $(0.215)$ & \\
\hline & & 0.146 & & 0.132 & $0.319^{*}$ & & 0.258 & & 0.18 \\
\hline & FDI (threshold) & $(0.157)$ & & $(0.152)$ & $(0.171)$ & & $(0.156)$ & & $(0.171)$ \\
\hline & MFN Tariff & $0.093^{*}$ & $0.173^{* * *}$ & $0.118^{*}$ & 0.051 & $0.088^{*}$ & 0.049 & $0.174 * * *$ & $0.124 * *$ \\
\hline & & $(0.054)$ & $(0.064)$ & $(0.061)$ & $(0.052)$ & $(0.052)$ & $(0.051)$ & $(0.066)$ & $(0.061)$ \\
\hline & No. of obs. & 7155 & 7155 & 7155 & 7155 & 7155 & 7155 & 7155 & 7155 \\
\hline & $\mathrm{R}^{2}$ & 0.093 & 0.093 & 0.092 & 0.092 & 0.093 & 0.092 & 0.093 & 0.093 \\
\hline
\end{tabular}

errors clustered on industry-year combinations are presented in parentheses. *, **, *** indicate statistical significance at the 10,5 and $1 \%$ level.

Moreover, our results suggest that other, albeit not all, aspects of openness affect firm performance. We find that high tariffs on foreign-produced material inputs are negatively correlated with firm productivity. The coefficient is statistically significant in 5 out of 8 cases. This result is in line with the findings by Amiti and Konings (2005) showing that trade liberalization benefits users of imported inputs. Consistent with the results of Javorcik (2004), we do not find evidence suggesting that access to material inputs produced by foreign investors affect the performance of domestic producers. Moving on to within industry effects, our results produce some weak evidence of positive spillovers from foreign presence in the same sector. The estimations also suggest that tariff protection in the same sector displays a positive correlation with firm performance. While this finding contrasts with the results on the effect of import competition on productivity in the existing literature, it is important to mention that our result is not directly comparable to those found in other analyses, due to the specific situation of the Czech Republic. Imports of manufacturing products from the European Union and its accession countries were entering the Czech Republic practically duty free throughout most of the period under study, and our tariff measure captures the residual competition offered by imports from non-EU countries. ${ }^{24}$

In order to interpret the size of our estimated coefficients, we undertake the following hypothetical exercises on the basis of models I and III in table 2. Assume that the level of services liberalization in the Czech Republic at the end of our time frame, as measured by the EBRD indices, were to drop to the level of Romania, which has made considerably less progress in liberalizing its services sectors according to the EBRD. In this case, our model would predict an average decrease in the productivity of downstream manufacturing sectors of the order of $4.8 \%$. With respect to foreign presence, simulating a one-standarddeviation increase in foreign presence in services industries would lead to a $3.8 \%$ increase in the productivity of downstream manufacturing firms.

In table 3, we present the same estimates based on TFP measures obtained using the Olley and Pakes method. These results lead to the same conclusions: We find a positive and significant relationship between the reform in services sectors, as reflected by the EBRD index, foreign presence and privatization, and the performance of Czech firms in downstream manufacturing. As before, the effect of privatization is statistically significant only when the capital share definition is used. The last result is not surprising as privatizing only a small share of an enterprise ( $10 \%$ is the threshold value in this case) is unlikely to have a

${ }^{24}$ Imports from the European Union accounted on average for $62.5 \%$ of all Czech imports during the period under study. In Appendix $\mathrm{G}$, we have estimated the same models as in table 2 using EU-preferential tariffs in addition to the MFN tariffs. While the preferential tariff measures are insignificant in these regressions, the results for services reform remain largely unchanged. 
profound effect on the control and thus the performance of the enterprise. Again, the presence of foreign services providers appears to have the most robust effect on the performance of Czech firms in downstream manufacturing.

As the next step, we estimate our model in first differences as specified in equation 4 . In this more demanding specification, the differencing removes all influences that are fixed at the level of the firm, industry or region, as did the firm fixed effects before. In addition, regional dummy variables in the differenced equation now purge all differences in trends that are specific to the region of operation. The estimates, based on the OLS productivity and presented in table 4, confirm our earlier conclusions. We find a positive and statistically significant correlation between the presence of foreign providers of services and the productivity of Czech firms relying on services inputs. As before, statistically significant effects are also found for the index of policy changes and the extent of privatization. We reach similar conclusions when we employ the TFP measures based on the Olley-Pakes approach (table 5). 
TABLE 4. Estimation in first differences using OLS productivities:

Productivity in domestic manufacturing firms and reform in upstream services sectors

\begin{tabular}{|c|c|c|c|c|c|c|c|c|}
\hline \multicolumn{2}{|c|}{ Dependent Variable: $\Delta \ln (\mathrm{TFP})$} & \multirow{2}{*}{$\frac{\mathrm{I}}{1.062 * * *}$} & \multirow[t]{2}{*}{ II } & \multirow[t]{2}{*}{ III } & \multirow[t]{2}{*}{ IV } & \multirow[t]{2}{*}{$\mathrm{V}$} & \multirow{2}{*}{$\frac{\mathrm{VI}}{0.781^{*}}$} & \multirow{2}{*}{$\frac{\mathrm{VII}}{1.108 * * *}$} \\
\hline Services input & EBRD & & & & & & & \\
\hline \multirow[t]{9}{*}{ linkages } & & $(0.400)$ & & & & & $(0.429)$ & $(0.404)$ \\
\hline & FDI (share) & & $7.274 * *$ & & & & $5.850 *$ & \\
\hline & & & $(3.133)$ & & & & $(3.314)$ & \\
\hline & FDI (threshold) & & & 1.996 & & & & $2.521^{*}$ \\
\hline & & & & $(1.468)$ & & & & $(1.419)$ \\
\hline & Concentration & & & & 0.188 & & 2.409 & 1.416 \\
\hline & & & & & $(3.554)$ & & $(3.634)$ & $(3.605)$ \\
\hline & Privatization (share) & & & & & $15.814 * *$ & & \\
\hline & & & & & & $(6.969)$ & & \\
\hline \multirow{6}{*}{$\begin{array}{l}\text { Manufacturing } \\
\text { input linkages }\end{array}$} & FDI (share) & -0.143 & 0.242 & & -0.279 & -0.146 & 0.120 & \\
\hline & & $(0.571)$ & $(0.634)$ & & $(0.640)$ & $(0.584)$ & $(0.636)$ & \\
\hline & FDI (threshold) & & & 0.027 & & & & 0.137 \\
\hline & & & & $(0.439)$ & & & & $(0.456)$ \\
\hline & MFN Tariff & $-0.211^{*}$ & $-0.369 * *$ & -0.225 & -0.155 & -0.210 & $-0.368 * *$ & $-0.323^{*}$ \\
\hline & & $(0.120)$ & $(0.185)$ & $(0.196)$ & $(0.124)$ & $(0.131)$ & $(0.180)$ & $(0.186)$ \\
\hline \multirow{8}{*}{$\begin{array}{l}\text { Within sector } \\
\text { effects }\end{array}$} & FDI (share) & -0.046 & -0.237 & & 0.034 & -0.011 & -0.191 & \\
\hline & & $(0.257)$ & $(0.290)$ & & $(0.291)$ & $(0.272)$ & $(0.287)$ & \\
\hline & FDI (threshold) & & & 0.015 & & & & -0.069 \\
\hline & & & & $(0.189)$ & & & & $(0.199)$ \\
\hline & MFN Tariff & $0.087^{*}$ & $0.155^{*}$ & 0.084 & 0.058 & 0.075 & $0.161^{*}$ & 0.135 \\
\hline & & $(0.052)$ & $(0.083)$ & $(0.089)$ & $(0.055)$ & $(0.057)$ & $(0.081)$ & $(0.082)$ \\
\hline & No. of obs. & 4197 & 4197 & 4197 & 4197 & 4197 & 4197 & 4197 \\
\hline & $\mathrm{R}^{2}$ & 0.02 & 0.02 & 0.019 & 0.018 & 0.02 & 0.02 & 0.02 \\
\hline
\end{tabular}

Given the tight supervision of progress in policy reform by the European Commission in preparation for EU accession, services policy choices can be considered largely exogenous. Nevertheless, in order to present some evidence that reverse causality is not likely to be a problem for the outcome variables in our estimation, we extend the lags of the independent variables in our equation to two years. The results from these specifications are presented in table 6 for OLS TFP measures and table 7 for Olley-Pakes TFP estimates. They demonstrate that our basic conclusion regarding the importance of foreign entry into services sectors holds when we expand the number of lags with which the independent variables enter the regressions. Since it is unlikely that the productivity of manufacturing firms today is relevant for FDI inflows into services sectors two years ago, we feel reasonably confident that reverse causation is not a problem in this specification. 
TABLE 5. Estimation in first differences using Olley-Pakes productivities:

Productivity in domestic manufacturing firms and reform in upstream services sectors

\begin{tabular}{|c|c|c|c|c|c|c|c|c|}
\hline \multicolumn{2}{|c|}{ Dependent Variable: $\Delta \ln (\mathrm{TFP})$} & \multirow{2}{*}{$\frac{\mathrm{I}}{1.138^{* * *}}$} & \multirow[t]{2}{*}{ II } & \multirow[t]{2}{*}{ III } & \multirow[t]{2}{*}{ IV } & \multirow[t]{2}{*}{$\mathrm{V}$} & \multirow{2}{*}{$\frac{\mathrm{VI}}{0.853^{*}}$} & \multirow{2}{*}{$\frac{\mathrm{VII}}{1.183 * * *}$} \\
\hline Services input & EBRD & & & & & & & \\
\hline \multirow[t]{9}{*}{ linkages } & & $(0.425)$ & & & & & $(0.452)$ & $(0.443)$ \\
\hline & FDI (share) & & $7.627 * *$ & & & & $6.171^{*}$ & \\
\hline & & & $(3.254)$ & & & & $(3.388)$ & \\
\hline & FDI (threshold) & & & 1.983 & & & & $2.544^{*}$ \\
\hline & & & & $(1.515)$ & & & & $(1.471)$ \\
\hline & Concentration & & & & 0.905 & & 3.278 & 2.572 \\
\hline & & & & & $(3.572)$ & & $(3.653)$ & $(3.642)$ \\
\hline & Privatization (share) & & & & & $18.931 * * *$ & & \\
\hline & & & & & & $(7.149)$ & & \\
\hline \multirow{6}{*}{$\begin{array}{l}\text { Manufacturing } \\
\text { input linkages }\end{array}$} & FDI (share) & 0.156 & 0.557 & & -0.022 & 0.169 & 0.401 & \\
\hline & & $(0.590)$ & $(0.634)$ & & $(0.662)$ & $(0.570)$ & $(0.641)$ & \\
\hline & FDI (threshold) & & & 0.11 & & & & 0.193 \\
\hline & & & & $(0.500)$ & & & & $(0.537)$ \\
\hline & MFN Tariff & $-0.199 *$ & $-0.364 *$ & -0.218 & -0.14 & -0.206 & $-0.366^{* *}$ & $-0.320^{*}$ \\
\hline & & $(0.116)$ & $(0.188)$ & $(0.193)$ & $(0.120)$ & $(0.130)$ & $(0.180)$ & $(0.184)$ \\
\hline \multirow{8}{*}{$\begin{array}{l}\text { Within sector } \\
\text { effects }\end{array}$} & FDI (share) & -0.19 & -0.389 & & -0.091 & -0.159 & -0.33 & \\
\hline & & $(0.262)$ & $(0.286)$ & & $(0.297)$ & $(0.266)$ & $(0.287)$ & \\
\hline & FDI (threshold) & & & -0.022 & & & & -0.092 \\
\hline & & & & $(0.214)$ & & & & $(0.235)$ \\
\hline & MFN Tariff & $0.091 *$ & $0.161^{*}$ & 0.091 & 0.061 & 0.08 & $0.171^{* *}$ & $0.145^{*}$ \\
\hline & & $(0.053)$ & $(0.087)$ & $(0.090)$ & $(0.056)$ & $(0.060)$ & $(0.083)$ & $(0.084)$ \\
\hline & No. of obs. & 4197 & 4197 & 4197 & 4197 & 4197 & 4197 & 4197 \\
\hline & $\mathrm{R}^{2}$ & 0.02 & 0.02 & 0.018 & 0.018 & 0.02 & 0.02 & 0.02 \\
\hline
\end{tabular}

The results presented in tables 6 and 7 also demonstrate that opening services sectors to FDI appears to be the key channel though which services liberalization benefits manufacturing firms. When proxies for foreign presence in services industries are included, the other measures of services liberalization fail to reach conventional significance levels. 
TABLE 6. Estimation with 2 year lags using OLS productivities:

Productivity in domestic manufacturing firms and reform in upstream services sectors

\begin{tabular}{|c|c|c|c|c|c|c|c|c|c|c|c|}
\hline \multicolumn{2}{|c|}{ Dependent Variable: $\ln (\mathrm{TFP})$} & \multirow[t]{2}{*}{ I } & \multirow[t]{2}{*}{ II } & \multirow{2}{*}{$\frac{\text { III }}{0.275}$} & \multirow{2}{*}{$\begin{array}{c}\text { IV } \\
0.571\end{array}$} & \multirow{2}{*}{$\frac{\mathrm{V}}{0.557}$} & \multirow{2}{*}{$\begin{array}{c}\text { VI } \\
0.801\end{array}$} & \multirow{2}{*}{$\frac{\text { VII }}{0.376}$} & \multirow{2}{*}{$\begin{array}{c}\text { VIII } \\
0.461\end{array}$} & \multirow{2}{*}{$\begin{array}{c}\mathrm{IX} \\
0.009\end{array}$} & \multirow{3}{*}{$\begin{array}{c}\mathrm{X} \\
0.107 \\
(1.002)\end{array}$} \\
\hline Services input & EBRD & & & & & & & & & & \\
\hline \multirow[t]{11}{*}{ linkages } & & & & $(0.854)$ & $(0.856)$ & $(0.885)$ & $(0.892)$ & $(0.860)$ & $(0.873)$ & $(0.973)$ & \\
\hline & FDI (share) & $2.796^{*}$ & & 2.583 & & $3.019 * *$ & & $3.964^{*}$ & & $3.536^{* *}$ & \\
\hline & & $(1.618)$ & & $(1.640)$ & & $(1.498)$ & & $(2.315)$ & & $(1.539)$ & \\
\hline & FDI (threshold) & & $2.044 * * *$ & & $1.974 * *$ & & $1.913 * *$ & & $3.056^{* *}$ & & $2.410^{* * *}$ \\
\hline & & & $(0.774)$ & & $(0.768)$ & & $(0.754)$ & & $(1.422)$ & & $(0.836)$ \\
\hline & Concentration & & & & & 5.027 & 4.778 & 5.533 & 4.738 & 5.047 & 3.803 \\
\hline & & & & & & $(4.448)$ & $(5.095)$ & $(4.634)$ & $(5.123)$ & $(4.625)$ & $(5.213)$ \\
\hline & Privatization (share) & & & & & & & -3.847 & -8.109 & & \\
\hline & & & & & & & & $(6.894)$ & $(8.291)$ & & \\
\hline & Privatization (threshold) & & & & & & & & & -42.403 & -47.615 \\
\hline & & & & & & & & & & $(37.922)$ & $(34.873)$ \\
\hline \multirow{6}{*}{$\begin{array}{l}\text { Manufacturing } \\
\text { input linkages }\end{array}$} & FDI (share) & 0.659 & & 0.656 & & 0.368 & & 0.299 & & 0.15 & \\
\hline & & $(0.402)$ & & $(0.405)$ & & $(0.482)$ & & $(0.498)$ & & $(0.543)$ & \\
\hline & FDI (threshold) & & -0.172 & & -0.139 & & -0.354 & & -0.266 & & -0.363 \\
\hline & & & $(0.424)$ & & $(0.427)$ & & $(0.475)$ & & $(0.507)$ & & $(0.481)$ \\
\hline & MFN Tariff & 0.084 & -0.014 & 0.085 & -0.025 & 0.054 & -0.009 & 0.046 & -0.032 & 0.066 & 0.001 \\
\hline & & $(0.109)$ & $(0.112)$ & $(0.108)$ & (0.112) & $(0.107)$ & $(0.112)$ & (0.109) & $(0.120)$ & $(0.111)$ & $(0.115)$ \\
\hline \multirow{8}{*}{$\begin{array}{l}\text { Within sector } \\
\text { effects }\end{array}$} & FDI (share) & $-0.287^{*}$ & & $-0.287^{*}$ & & -0.16 & & -0.142 & & -0.091 & \\
\hline & & $(0.162)$ & & $(0.162)$ & & $(0.206)$ & & $(0.210)$ & & $(0.222)$ & \\
\hline & FDI (threshold) & & -0.134 & & -0.153 & & -0.026 & & -0.06 & & -0.029 \\
\hline & & & $(0.127)$ & & $(0.127)$ & & $(0.185)$ & & $(0.200)$ & & $(0.191)$ \\
\hline & MFN Tariff & -0.039 & 0.01 & -0.04 & 0.015 & -0.018 & 0.015 & -0.01 & 0.029 & -0.024 & 0.005 \\
\hline & & $(0.052)$ & $(0.053)$ & $(0.051)$ & $(0.053)$ & $(0.052)$ & $(0.052)$ & $(0.055)$ & $(0.058)$ & $(0.055)$ & $(0.054)$ \\
\hline & No. of obs. & 5662 & 5662 & 5662 & 5662 & 5662 & 5662 & 5662 & 5662 & 5662 & 5662 \\
\hline & $\mathrm{R}^{2}$ & 0.043 & 0.043 & 0.042 & 0.043 & 0.043 & 0.043 & 0.042 & 0.043 & 0.043 & 0.044 \\
\hline
\end{tabular}

The Inputs Linkage variables are weighted by the respective I/O coefficient. All regressors are lagged two years. All models include firm and year fixed effects. Robust standard errors clustered on industry-year combinations are presented in parentheses. ${ }^{*}, * *, * *$ indicate statistical significance at the 10,5 and $1 \%$ level. 
TABLE 7. Estimation with 2 year lags using Olley-Pakes productivities:

Productivity in domestic manufacturing firms and reform in upstream services sectors

\begin{tabular}{|c|c|c|c|c|c|c|c|c|c|c|c|}
\hline \multicolumn{2}{|c|}{ Dependent Variable: $\ln (\mathrm{TFP})$} & \multirow[t]{2}{*}{ I } & \multirow[t]{2}{*}{ II } & \multirow{2}{*}{$\frac{\text { III }}{-0.036}$} & \multirow{2}{*}{$\frac{\mathrm{IV}}{0.114}$} & \multirow{2}{*}{$\frac{\mathrm{V}}{0.375}$} & \multirow{2}{*}{$\frac{\mathrm{VI}}{0.471}$} & \multirow{2}{*}{$\begin{array}{c}\text { VII } \\
0.218\end{array}$} & \multirow{2}{*}{$\frac{\text { VIII }}{0.296}$} & \multirow{2}{*}{$\frac{\mathrm{IX}}{-0.163}$} & \multirow{2}{*}{$\frac{X}{-0.117}$} \\
\hline Services input & EBRD & & & & & & & & & & \\
\hline \multirow[t]{11}{*}{ linkages } & & & & $(0.865)$ & $(0.864)$ & $(0.864)$ & $(0.854)$ & $(0.851)$ & $(0.836)$ & $(0.937)$ & $(0.948)$ \\
\hline & FDI (share) & 2.054 & & 2.082 & & $2.719^{*}$ & & 3.541 & & $3.225 * *$ & \\
\hline & & $(1.753)$ & & $(1.754)$ & & $(1.579)$ & & $(2.443)$ & & $(1.578)$ & \\
\hline & FDI (threshold) & & $1.631^{*}$ & & $1.617^{*}$ & & $1.523^{*}$ & & 2.111 & & $1.944 * *$ \\
\hline & & & $(0.821)$ & & $(0.813)$ & & $(0.777)$ & & $(1.477)$ & & $(0.832)$ \\
\hline & Concentration & & & & & $7.332 *$ & 7.409 & $7.773 *$ & 7.388 & 7.352 & 6.583 \\
\hline & & & & & & $(4.371)$ & $(5.056)$ & $(4.543)$ & $(5.082)$ & $(4.517)$ & $(5.178)$ \\
\hline & Privatization (share) & & & & & & & -3.346 & -4.177 & & \\
\hline & & & & & & & & $(6.623)$ & $(8.261)$ & & \\
\hline & Privatization (threshold) & & & & & & & & & -41.61 & -40.323 \\
\hline & & & & & & & & & & $(32.277)$ & $(31.488)$ \\
\hline \multirow{6}{*}{$\begin{array}{l}\text { Manufacturing } \\
\text { input linkages }\end{array}$} & FDI (share) & 0.664 & & 0.665 & & 0.245 & & 0.185 & & 0.031 & \\
\hline & & $(0.428)$ & & $(0.427)$ & & $(0.491)$ & & $(0.501)$ & & $(0.536)$ & \\
\hline & FDI (threshold) & & 0.01 & & 0.017 & & -0.316 & & -0.271 & & -0.324 \\
\hline & & & $(0.428)$ & & $(0.430)$ & & $(0.457)$ & & $(0.492)$ & & $(0.463)$ \\
\hline & MFN Tariff & 0.146 & 0.056 & 0.146 & 0.054 & 0.101 & 0.077 & 0.094 & 0.066 & 0.113 & 0.086 \\
\hline & & $(0.106)$ & $(0.110)$ & $(0.106)$ & $(0.112)$ & $(0.103)$ & $(0.111)$ & $(0.106)$ & $(0.120)$ & $(0.107)$ & $(0.114)$ \\
\hline \multirow{8}{*}{$\begin{array}{l}\text { Within sector } \\
\text { effects }\end{array}$} & FDI (share) & $-0.355^{*}$ & & $-0.355^{*}$ & & -0.17 & & -0.154 & & -0.102 & \\
\hline & & $(0.181)$ & & $(0.181)$ & & $(0.219)$ & & $(0.218)$ & & $(0.226)$ & \\
\hline & FDI (threshold) & & -0.184 & & -0.187 & & 0.009 & & -0.009 & & 0.007 \\
\hline & & & $(0.124)$ & & $(0.126)$ & & $(0.179)$ & & $(0.193)$ & & $(0.184)$ \\
\hline & MFN Tariff & -0.06 & -0.017 & -0.06 & -0.016 & -0.028 & -0.017 & -0.021 & -0.009 & -0.034 & -0.025 \\
\hline & & $(0.051)$ & $(0.052)$ & $(0.051)$ & $(0.053)$ & $(0.050)$ & $(0.052)$ & $(0.053)$ & $(0.058)$ & $(0.053)$ & $(0.053)$ \\
\hline & No. of obs. & 5662 & 5662 & 5662 & 5662 & 5662 & 5662 & 5662 & 5662 & 5662 & 5662 \\
\hline & $\mathrm{R}^{2}$ & 0.042 & 0.042 & 0.042 & 0.042 & 0.042 & 0.042 & 0.042 & 0.042 & 0.043 & 0.043 \\
\hline
\end{tabular}

The Inputs Linkage variables are weighted by the respective I/O coefficient. All regressors are lagged two years. All models include firm and year fixed effects. Robust standard errors clustered on industry-year combinations are presented in parentheses. ${ }^{*}, * * *$ indicate statistical significance at the 10,5 and $1 \%$ level. 
In the final robustness check, we aim to ensure that endogeneity is not a concern for our FDI variables. We instrument for foreign presence in Czech services industries by taking advantage of the fact that two neighboring countries, Slovakia and Hungary, were also expected to liberalize services industries in preparation for their EU accession, which took place on May 1, 2004. We use the EBRD index capturing progress in their reforms, weighted by the Czech input-output coefficients, to instrument for foreign presence in Czech services industries:

services_linkage_IV Sllovak $=\sum_{k} a_{j k}^{\text {Czech }} \cdot$ liberalization_index ${ }_{k t}^{\text {Slovak }}$
ervices_linkage_IV $V_{j t}^{\text {Hungary }}=\sum_{k} a_{j k}^{\text {Czech }} \cdot$ liberalization_index ${ }_{k t}^{\text {Hungary }}$

The estimation results, presented in table 8 , suggest that these instruments are good predictors of foreign presence in services industries when the capital share definition is used but less so in the case of the threshold definition. The test of excluded instruments and the overidentification test confirm the validity of the instruments.

TABLE 8. Instrumenting for foreign presence in services industries

Productivity in domestic manufacturing firms and reform in upstream services sectors

\begin{tabular}{|c|c|c|c|c|c|}
\hline \multicolumn{2}{|c|}{ Dependent Variable: $\ln (\mathrm{TFP})$} & \multicolumn{2}{|c|}{ OLS Productivity } & \multicolumn{2}{|c|}{ Olley-Pakes Productivity } \\
\hline & & I & II & III & IV \\
\hline \multirow{4}{*}{$\begin{array}{l}\text { Services input } \\
\text { linkages }\end{array}$} & FDI (share) & $9.150 * *$ & & $8.593 * *$ & \\
\hline & & $(4.162)$ & & $(4.216)$ & \\
\hline & FDI (threshold) & & $11.515^{*}$ & & 10.481 \\
\hline & & & $(6.883)$ & & $(7.041)$ \\
\hline \multirow{6}{*}{$\begin{array}{l}\text { Manufacturing } \\
\text { input linkages }\end{array}$} & FDI (share) & -0.045 & & 0.231 & \\
\hline & & $(0.775)$ & & $(0.829)$ & \\
\hline & FDI (threshold) & & 0.265 & & 0.402 \\
\hline & & & $(0.955)$ & & $(1.010)$ \\
\hline & MFN Tariff & $-0.477 * *$ & $-0.922 *$ & $-0.409 *$ & -0.809 \\
\hline & & $(0.233)$ & $(0.559)$ & $(0.235)$ & $(0.580)$ \\
\hline \multirow{8}{*}{$\begin{array}{l}\text { Within sector } \\
\text { effects }\end{array}$} & FDI (share) & -0.073 & & -0.224 & \\
\hline & & $(0.329)$ & & $(0.334)$ & \\
\hline & FDI (threshold) & & -0.368 & & -0.392 \\
\hline & & & $(0.532)$ & & $(0.538)$ \\
\hline & MFN Tariff & $0.238^{* *}$ & $0.434 *$ & $0.218^{* *}$ & 0.394 \\
\hline & & $(0.108)$ & $(0.251)$ & $(0.109)$ & $(0.261)$ \\
\hline & Hansen J statistic & 0.49 & 0.14 & 0.78 & 0.30 \\
\hline & p-value & 0.48 & 0.71 & 0.38 & 0.59 \\
\hline \multirow{8}{*}{$\begin{array}{l}\text { Coefficients on } \\
\text { instrumental variables in } \\
\text { stage I }\end{array}$} & Weighted EBRD index for & $0.111 * * *$ & 0.086 & $0.111^{* * *}$ & 0.086 \\
\hline & Slovakia & $(0.027)$ & $(0.056)$ & $(0.027)$ & $(0.056)$ \\
\hline & Weighted EBRD index for & 0.048 & -0.082 & 0.048 & -0.082 \\
\hline & Hungary & $(0.233)$ & $(0.503)$ & $(0.233)$ & $(0.503)$ \\
\hline & F-statistic & 13.78 & 2.36 & 13.78 & 2.36 \\
\hline & p-value & 0.00 & 0.12 & 0.00 & 0.12 \\
\hline & Shea $\mathrm{R}^{2}$ & 0.35 & 0.05 & 0.35 & 0.05 \\
\hline & $\mathrm{R}^{2}$ & 6875 & 6875 & 6875 & 6875 \\
\hline
\end{tabular}

The Inputs Linkage variables are weighted by the respective I/O coefficient. All regressors are lagged one year. All models include firm and year fixed effects. Robust standard errors clustered on industry are presented in parentheses. ${ }^{*}, * *, * *$ indicate statistical significance at the 10,5 and $1 \%$ level. 
The results from the instrumental variable approach are consistent with our earlier findings. They suggest a positive and statistically significant relationship between the presence of foreign services providers and the performance of Czech manufacturing firms relying on services inputs. This is true for the capital share definition both when the OLS and the Olley-Pakes based TFP measures are used. In the case of the threshold definition, the coefficient is statistically significant only in the case of OLS productivity, but this may be due to weaker performance of the instruments in explaining the threshold based proxy.

To summarize, our findings of a positive relationship between liberalization of services sectors, in particular opening of services sectors to foreign providers, and downstream manufacturing performance are consistent with a productivity-enhancing effect of a reform in services. They suggest that manufacturing firms relying more on inputs from liberalized services sectors or purchasing inputs from foreign services providers tend to exhibit a higher total factor productivity. These findings are robust to controlling for unobservable firm characteristics, for changes in other aspects of openness and for systematic differences in performance across regions and time periods. They are also robust to instrumenting for foreign presence in services industries.

\section{Conclusions}

In this paper, we create measures of reform in services sectors and combine them with information on the degree to which manufacturing firms rely on intermediate inputs from services industries. This allows us to analyze the relationship between services liberalization and downstream manufacturing performance. We capture services liberalization in four ways: (i) using an index of policy reforms created by the European Bank for Reconstruction and Development (EBRD) taking into account all aspects of services liberalization, including both the domestic and the international dimension; (ii) considering the share of services output provided by foreign-owned firms; (iii) focusing on the share of services provided by private and privatized firms; and (iv) considering the extent of competition in services sectors.

Our results suggest two conclusions. First, we find that services policy matters for manufacturing performance as manifested in the strong correlation between services sector reform and the productivity of local producers relying on services as intermediate inputs. This finding is robust to several different econometric specifications, including controlling for unobservable firm heterogeneity and for other aspects of openness. Second, we find evidence suggesting that opening services sectors to foreign providers is a key channel through which services reforms affect downstream productivity in manufacturing. This finding is robust to instrumenting for the extent of foreign presence in services industries.

As most barriers to foreign investment today are not in goods but in services, we hope that our findings will provide support for further liberalization of services industries and opening of services sectors to foreign providers. 


\section{References}

Aitken, Brian and Ann Harrison (1999). Do Domestic Firms Benefit from Direct Foreign Investment? Evidence from Venezuela. American Economic Review 89(3): 605-618

Amiti, Mary and Joseph Konings (2005). Trade Liberalization, Intermediate Inputs and Productivity: Evidence from Indonesia. CEPR Discussion Paper 5104

Arnold, Jens and Katrin Hussinger (2005). Export Behavior and Firm Productivity in German Manufacturing: A Firm-Level Analysis. Review of World Economics/ Weltwirtschaftliches Archiv 141(2): 219-243

Arnold, Jens and Beata S. Javorcik (2005). Gifted Kids or Pushy Parents? Foreign Acquisitions and Firm Performance in Indonesia. World Bank Policy Research Working Paper No. 3597

Conway, Paul, Donato de Rosa, Giuseppe Nicoletti and Faye Steiner (2006). Regulation, Competition and Productivity Convergences. OECD Economics Department Working Papers No. 509.

Djankov, Simeon and Bernard Hoekman (2000). Foreign Investment and Productivity Growth in Czech Enterprises. The World Bank Economic Review 14(1): 49-64

Eschenbach, Felix and Bernard Hoekman (2006). Services Policy Reform and Economic Growth in Transition Economies, 1990-2004. Review of World Economics/ Weltwirtschaftliches Archiv, forthcoming

Fernald, John (1999). Roads to Prosperity? Assessing the Link Between Public Capital and Productivity. American Economic Review 89(3): 619-638

Fernandes, Ana (2006). Trade Policy, Trade Volumes and Plant-Level Productivity in Colombian Manufacturing Industries. Journal of International Economics, forthcoming

Fink, Carsten, Aaditya Mattoo and Cristina Neagu (2005). Assessing the Impact of Communication Costs on International Trade. Journal of International Economics 67(2): 428-445

Francois, Joseph (1990). Producer Services, Scale and the Division of Labor. Oxford Economic Papers 42: 715-729

Francois, Joseph and Ian Wooton (2005). Market Structure and Market Access. CEPR Discussion Paper 5135

Freund, Caroline and Diana Weinhold (2002). The Internet and International Trade in Services. American Economic Review 92(2): 236-240

Goh, Chor-ching and Beata S. Javorcik (2006). Trade Protection and Industry Wage Structure in Poland in Globalization and Poverty, A. Harrison, ed., University of Chicago Press, forthcoming

Hanousek, Jan, Kocenda, Evzen and Lizal, Lubomir (2004). Tale of the Czech Transition: Understanding the Challenges Ahead. MatfyzPress, Prague.

Haskel, Jonathan E., Sonia C. Pereira, and Matthew J. Slaughter. (2002). Does Inward Foreign Direct Investment Boost the Productivity of Domestic Firms? NBER Working Paper No. 8724

Hoekman, Bernard (2006). Trade in Services at 25: Theory, Policy and Evidence. World Bank, mimeo

Javorcik, Beata S. (2004). Does Foreign Direct Investment Increase the Productivity of Domestic Firms? In Search of Spillovers Through Backward Linkages. American Economic Review 94(3): 605-627

Javorcik, Beata S., Wolfgang Keller and James Tybout (2006). Openness and Industrial Response in a WalMart World: A Case Study of Mexican Soaps, Detergents and Surfactant Producers. NBER Working Paper No. 12457

Keller, Wolfgang, and Stephen Yeaple (2003). Multinational Enterprises, International Trade and Productivity Growth: Firm Level Evidence from the United States." NBER Working Paper No. 9504 
Konings, Jozef (2001). The Effects of Foreign Direct Investment on Domestic Firms. Economics of Transition 9(3): 619- 633.

Krishna, Pravin and Devashish Mitra (1998). Trade liberalization, market discipline and productivity growth: new evidence from India. Journal of Development Economics 56(2): 447-462

Kugler, Maurice (2006). Spillovers from Foreign Direct Investment: Within or Between Industries? Journal of Development Economics. forthcoming

Mattoo, Aaditya, Randeep Rathindran and Arvin Subramanian (2006). Measuring Services Trade Liberalization and Its Impact on Economic Growth: An Illustration. Journal of Economic Integration 21(1): 64-98

Muendler, Marc-Andreas (2004). Trade, Technology, and Productivity: A Study of Brazilian Manufacturers, 1986-1998. University of California, San Diego, mimeo

Nicoletti, Giuseppe and Stefano Scarpetta (2003). Regulation, Productivity and Growth: OECD Evidence, Economic Policy, Vol. 0(36):9-51

Nollen, Stanley, Zdenek Kudrna and Roman Pazdernik (2005). The Troubled Transition of Czech Banks to Competitive Markets. Georgetown University McDonough School of Business, mimeo

Olley, G. Steven and Ariel Pakes (1996). The Dynamics of Productivity in the Telecommunications Equipment Industry. Econometrica 64(6): 1263-97

Pavcnik, Nina (2002). Trade liberalization, Exit, and Productivity improvements: Evidence from Chilean Plants. Review of Economic Studies 69: 245-76

Rajan, Raghuram G. and Luigi Zingales (1998). Financial Dependence and Growth. American Economic Review 88: 559-586.

Rutherford, Thomas, David Tarr and Oleksandr Shepotylo 2005. The Impact on Russia of WTO Accession and the Doha Agenda: The Importance of Liberalization of Barriers Against Foreign Direct Investment in Services for Growth and Poverty Reduction. World Bank Policy Research Working Paper No. 3725

UNCTAD (2004). World Investment Report. The Shift Towards Services. New York and Geneva.

Tybout, James (2003). Plant- and Firm-level Evidence on the 'New' Trade Theories, in E. Kwan Choi and James Harrigan, ed., Handbook of International Trade, Oxford: Basil-Blackwell

WTO (2001). Trade Policy Review: Czech Republic. Geneva. 
Appendix A. Services policy reform in the Czech Republic, 1998-2003

In order to give some examples of the profound changes that have taken place in Czech services sectors during the period covered by our study (1998-2003), we present a detailed description of the regulatory reforms in the banking, telecommunications and energy sectors. The information below draws largely on the yearly Accession Protocols of the European Commission and the WTO Trade Policy Review for the Czech Republic (2001).

In the banking sector, the privatization of the remaining four large state-controlled banks began with the sale of IPB in March 1998 and the call for expression of interest for CSOB in July 1998. Regulatory improvements were enacted in the same year to separate banks' engagement in the enterprise sector, which was perceived as one of the reasons for banks' soft stance vis-à-vis bad debtors. ${ }^{25}$ Foreign investors were treated on equal terms with domestic ones as of 1998, and the supervisory powers of the central bank were strengthened. In 1999, the government published a precise and ambitious timetable for the remaining privatizations in banking. In June, a majority stake in CSOB was sold to foreign investors. Another bank, CS, with a public share of $45 \%$, was completely privatized in March 2000. In preparation for privatization, many historic debt positions were moved into a public fund, with the state covering the cost of the writeoffs. This was particularly relevant for CS and even more so KB, the last remaining public bank awaiting privatization. By 2000, two thirds of banking assets were foreign owned. In 2001, KB was privatized after a massive bailout by the state. This completed the banking privatizations, and left $90 \%$ of banking assets in foreign-controlled banks, with 27 out of 40 commercial banks being foreign owned. In 2002, after another legal reform, the EU deemed the banking sector in the Czech Republic to be in compliance with the acquis communautaire.

In the telecommunications sector, the monopoly fixed line operator was majority public-owned in 1998, and there was no independent regulator for the sector. The two ministries in charge of regulation faced a conflict of interest by simultaneously exercising the state's controlling property rights in several operating companies. In mobile services, there were two providers with $51 \%$ public ownership and the remaining capital held mostly by foreign investors. In early 2000, the Telecommunications Act established an independent regulator and determined that January 1, 2001 would be the end of the fixed line monopoly of the incumbent. New licenses were issued in advance of the market opening in 2001, and the regulator made a number of crucial decisions regarding interconnection. Yet, as interconnection prices were above comparable prices in the EU and the provision of carrier selection facilities had not been addressed, the EU called for immediate action. A third mobile operator entered the market in 2000 , with $100 \%$ foreign ownership, and in 2001 the foreign private investor in one of the two mobile companies operating since 1996 increased its shares to $60 \%$. Carrier selection on a call-by-call basis was introduced in July 2002 . The developments, combined with reduced interconnection charges, notably increased the level of competition. However, the fixed line market was still largely controlled by a single operator in which the State held a majority stake and which was not fully commercialized. For these reasons, it had been difficult for alternative operators to compete even though the market had legally been open. In August 2002, the government decided to privatize the state's majority stake in the incumbent fixed line operator. Meanwhile, strong competition has evolved in mobile services, which have become a direct competitor to fixed line services.

In the energy sector, a regulatory administration was established in 1998, although its independence was still limited. In January 1999, a transmission system operator for electricity was set up as a $100 \%$ subsidiary of the national electricity company, separating the production and transmission accounts as required by the EU Electricity Directive. However, the dominant producer still held a monopoly for transmission, transit, import and export of electricity. Tariffs, which had traditionally been set below costs, were revised in 1999, which implied an increase in the maximum prices for gas and power for households effective in early 2000.

\footnotetext{
${ }^{25}$ Nollen, Kudrna and Pazdernik (2005) describe the conflict of interest stemming from the fact that banks' investment funds owned a sizeable stake in industrial companies. As lenders, the banks were expected to apply prudent lending criteria based on the creditworthiness of the borrower. However, as owners via investment funds, the banks had an incentive to look for short-term returns and to stave off losses and bankruptcy and therefore preferred to lend than to foreclose or force default. Another unusual characteristic of the Czech banking system was that managers of bank investment funds were in the awkward position of representing their owners in a competing bank.
} 
Two regional energy distributors in South Bohemia were privatized in 2000, and authorities embarked on a gradual process of price liberalization, which aimed at eliminating cross-subsidies. On 1 January 2001, a new Energy Act came into force providing for a gradual liberalization of the electricity and gas markets, including third party access starting in 2002. Following further price liberalization in both segments, the EU Commission concluded that the alignment of prices for private households with cost recovery levels was achieved for electricity and was near completion for gas by 2001. The same year saw the establishment of an independent regulator, the Energy Regulatory Office (ERO). It is funded from a separate chapter of the state budget, with its principle responsibility being the promotion of competition. The regulator can pass secondary legislation, grant market licenses and set market rules. In 2002, the ERO issued decrees regulating the construction of and access to the electricity and gas network infrastructure, the cost and revenue calculation for utilities and licensing rules. In January 2002, the market for entities consuming over $40 \mathrm{GWh}$ of electricity annually became fully liberalized. This led to a reduction in electricity prices for this market segment, which has 65 eligible customers representing approximately $30 \%$ of the Czech market. The privatization of the Czech monopoly gas importer and owner of the transit network, together with shares giving majority stakes in seven out of eight regional gas monopoly distributors was concluded in May 2002. In the electricity segment, the incumbent operator CEZ was restructured in 2002 and sold its majority stake in the electricity transmission system operator. Thanks to the privatization of major players in the gas market, the restructuring of electricity utilities and the broadly cost-reflective electricity prices, in 2002 the European Commission was able to deem the Czech gas and electricity sectors to be well prepared for the competitive EU-internal energy market. 
Appendix B. The survey questions.

The information in Figures 3 comes from a survey of Czech firms conducted on behalf of the World Bank in 2004. The exact question asked in the survey were as follows:

"There were several changes which Czech legislation has enabled since the year 1989. Please tell us if in your opinion the following facts have had a positive, negative or no impact on the services' access, their price, quality and range of services.

1. Since 1995 the Czech legislation has allowed foreign companies to invest into the telecommunication market in your country.

2. A few years ago, foreign companies were allowed by Czech legislation to provide accounting and auditing services in the CR.

3. In 2001, there was a major impulse boosting the privatization and foreign ownership of major banking companies.

4. A few years ago, Czech legislation allowed foreign companies to provide insurance services in CR.

5. A few years ago, Czech legislation allowed foreign companies to provide freight and transport services in CR."

Separate answers were collected for impact on access, prices, quality and range of each type of services. 
Appendix C. Data cleaning procedure.

All the variables in our data set are subject to missing values. Missing values in firm output created a particular problem when calculating the foreign output shares at the sector level. A large firm with a missing value for output in a given year can lead to bumps in the foreign output share of the respective industry if no correction is made. Hence rather than taking a missing value as a zero, we used linear interpolation to estimate the firm output in a year in which it was missing and we could not obtain the information from the company website. Although imperfect, the interpolated output is most likely a better approximation of the true value than a value of zero. Interpolated values, however, were used only for the construction of the foreign output shares at the sector level, not in our estimation of firm performance.

We also encountered cases of missing information on the country of origin of the firm owner. In these cases, we looked up information on the owners from other publicly available sources and tried to determine whether they were Czech or foreign. This usually allowed us to eliminate any residual doubts. For the top 5 companies in each sector and year, we additionally verified any available information about foreign owners and their date of entry by looking at annual reports and information on the company websites. For smaller firms, we replaced missing values of the record date with the release date of the Amadeus version from which the record originated. In the cases where owners were not physical persons, we used information about the ultimate owners (that is, shareholders in the owner company) and were thus able to account for cases of indirect foreign ownership. We also allowed for the possibility of a firm becoming foreign through a change in shareholders of a possible intermediate owner.

In some cases, figures reported in Amadeus appeared to be key punch errors, and we developed several rules to clean the data by excluding firms with unlikely patterns from our sample. We excluded a firm from our sample if it reported negative values of payments to labor, of intermediate inputs or of capital stock, and wherever intermediate inputs exceeded the value of output. 
Appendix D. Production Function Estimation

Table D1. Estimated production function coefficients

\begin{tabular}{|c|c|c|c|c|c|c|}
\hline \multirow[b]{2}{*}{ Sector } & \multicolumn{3}{|c|}{ OLS estimation } & \multicolumn{3}{|c|}{ Olley-Pakes estimation } \\
\hline & Labor & $\begin{array}{l}\text { Material } \\
\text { and } \\
\text { services } \\
\text { inputs }\end{array}$ & Capital & Labor & $\begin{array}{l}\text { Material } \\
\text { and } \\
\text { services } \\
\text { inputs }\end{array}$ & Capital \\
\hline Food and beverages & 0.42 & 0.46 & 0.05 & 0.40 & 0.40 & 0.10 \\
\hline Textiles & 0.22 & 0.66 & 0.06 & 0.16 & 0.64 & 0.07 \\
\hline Wearing apparel & 0.32 & 0.49 & 0.06 & 0.36 & 0.48 & 0.06 \\
\hline Leather, luggage & 0.29 & 0.37 & 0.10 & 0.50 & 0.25 & 0.16 \\
\hline $\begin{array}{l}\text { Wood and wood products; paper } \\
\text { and paper products; furniture; } \\
\text { manufacturing n.e.c. }\end{array}$ & 0.32 & 0.49 & 0.07 & 0.24 & 0.55 & 0.13 \\
\hline Printing and publishing & 0.72 & 0.26 & -0.03 & 0.75 & 0.26 & 0.04 \\
\hline $\begin{array}{l}\text { Chemical, rubber and plastic } \\
\text { products }\end{array}$ & 0.36 & 0.44 & 0.10 & 0.37 & 0.37 & -0.03 \\
\hline $\begin{array}{l}\text { Other non-metallic mineral } \\
\text { products }\end{array}$ & 0.29 & 0.54 & 0.11 & 0.24 & 0.49 & 0.08 \\
\hline Basic metal products & 0.20 & 0.58 & 0.16 & 0.22 & 0.58 & 0.09 \\
\hline Fabricated metal products & 0.33 & 0.47 & 0.05 & 0.26 & 0.48 & 0.02 \\
\hline Machinery and equipment & 0.35 & 0.52 & 0.01 & 0.32 & 0.53 & 0.11 \\
\hline $\begin{array}{l}\text { Office and computing machinery; } \\
\text { electrical machinery and } \\
\text { apparatus }\end{array}$ & 0.37 & 0.37 & 0.07 & 0.32 & 0.36 & 0.05 \\
\hline $\begin{array}{l}\text { Radio, TV, communications } \\
\text { equipment; medical, precision and } \\
\text { optical instruments }\end{array}$ & 0.34 & 0.35 & 0.10 & 0.42 & 0.36 & 0.27 \\
\hline $\begin{array}{l}\text { Motor vehicles; other transport } \\
\text { equipment }\end{array}$ & 0.16 & 0.60 & 0.12 & 0.34 & 0.52 & 0.02 \\
\hline
\end{tabular}




\section{Appendix E. One Stage Estimation}

TABLE E1. One stage approach:

Productivity in domestic manufacturing firms and reform in upstream services sectors

\begin{tabular}{|c|c|c|c|c|c|c|c|c|}
\hline \multicolumn{2}{|c|}{ Dependent Variable: $\ln (\mathrm{TFP})$} & I & II & III & IV & $\mathrm{V}$ & VI & VII \\
\hline \multirow{10}{*}{$\begin{array}{l}\text { Services input } \\
\text { linkages }\end{array}$} & EBRD & $0.641 *$ & & & & & & \\
\hline & & $(0.339)$ & & & & & & \\
\hline & FDI (share) & & $3.947 * *$ & & & & $4.545^{* * *}$ & \\
\hline & & & $(1.717)$ & & & & $(1.714)$ & \\
\hline & FDI (threshold) & & & $1.426^{*}$ & & & & $1.516^{*}$ \\
\hline & & & & $(0.829)$ & & & & $(0.811)$ \\
\hline & Concentration & & & & 1.922 & & 3.65 & 4.197 \\
\hline & & & & & $(2.901)$ & & $(2.835)$ & $(2.911)$ \\
\hline & Privatization (share) & & & & & $9.386 * *$ & & \\
\hline & & & & & & $(4.266)$ & & \\
\hline \multirow{6}{*}{$\begin{array}{l}\text { Manufacturing } \\
\text { input linkages }\end{array}$} & FDI (share) & 0.358 & 0.573 & & 0.063 & 0.391 & 0.395 & \\
\hline & & $(0.394)$ & $(0.405)$ & & $(0.413)$ & $(0.387)$ & $(0.437)$ & \\
\hline & FDI (threshold) & & & 0.127 & & & & -0.054 \\
\hline & & & & $(0.350)$ & & & & $(0.373)$ \\
\hline & MFN Tariff & -0.114 & -0.203 & -0.160 & -0.059 & -0.100 & $-0.232^{*}$ & -0.159 \\
\hline & & $(0.104)$ & $(0.127)$ & $(0.116)$ & $(0.097)$ & $(0.095)$ & $(0.130)$ & $(0.117)$ \\
\hline \multirow{8}{*}{$\begin{array}{l}\text { Within sector } \\
\text { effects }\end{array}$} & FDI (share) & -0.136 & -0.244 & & 0.013 & -0.105 & -0.168 & \\
\hline & & $(0.172)$ & $(0.174)$ & & $(0.186)$ & $(0.173)$ & $(0.190)$ & \\
\hline & FDI (threshold) & & & -0.023 & & & & 0.081 \\
\hline & & & & $(0.146)$ & & & & $(0.165)$ \\
\hline & MFN Tariff & 0.072 & $0.111^{*}$ & $0.094^{*}$ & 0.05 & 0.054 & $0.129 * *$ & $0.099 *$ \\
\hline & & $(0.053)$ & $(0.062)$ & $(0.057)$ & $(0.050)$ & $(0.048)$ & $(0.064)$ & $(0.058)$ \\
\hline & No. of obs. & 7155 & 7155 & 7155 & 7155 & 7155 & 7155 & 7155 \\
\hline & $\mathrm{R}^{2}$ & 0.59 & 0.59 & 0.59 & 0.589 & 0.59 & 0.59 & 0.59 \\
\hline
\end{tabular}


Appendix F. A description of the EBRD indicators of services sector reforms

The EBRD indicators of services sector reform come from the publication "Transition Report 2004". Sector-specific time-varying indices are available for banking, telecommunications, electric power, railway transport, road transport, and water and waste water. In addition, the publication constructs an aggregate index of infrastructure reform, and an index for financial institutions. For those sectors where no specific sector index was available, we used an overall services index, created as the average of the infrastructure and financial institutions indices. Below we reproduce a description of the indices, as outlined in pages 199-204 of EBRD (2004).

"The transition indicator scores [...] reflect the judgment of the EBRD's Office of the Chief Economist about country-specific progress in transition. The scores are based on the following classification system, which was originally developed in the 1994 Transition Report, but has been refined and amended in subsequent Reports.

"+" and "--" ratings are treated by adding 0.33 and subtracting 0.33 from the full value. The average is obtained by rounding down, e.g. a score of 2.6 is treated as $2+$, but a score of 2.8 is treated as 3 --.

\section{Infrastructure reform}

The ratings are calculated as the average of five infrastructure reform indicators covering electric power, roads, railways, telecommunications, water and waste water. The classification system used for these five indicators is detailed below.

\section{Banking reform and interest rate liberalisation}

1 Little progress beyond establishment of a two-tier system.

2 Significant liberalisation of interest rates and credit allocation; limited use of directed credit or interest rate ceilings.

3 Substantial progress in establishment of bank solvency and of a framework for prudential supervision and regulation; full interest rate liberalisation with little preferential access to cheap refinancing; significant lending to private enterprises and significant presence of private banks.

4 Significant movement of banking laws and regulations towards BIS standards; well-functioning banking competition and effective prudential supervision; significant term lending to private enterprises; substantial financial deepening.

4+ Standards and performance norms of advanced industrial economies: full convergence of banking laws and regulations with BIS standards; provision of full set of competitive banking services.

\section{Electric power}

1 Power sector operates as government department with few commercial freedoms or pressures. Average prices well below costs, with extensive cross-subsidies. Monolithic structure, with no separation of different parts of the business.

2 Power company distanced from government, but there is still political interference. Some attempt to harden budget constraints, but effective tariffs are low. Weak management incentives for efficient performance. Little institutional reform and minimal, if any, private sector involvement.

3 Law passed providing for full-scale restructuring of industry, including vertical unbundling through account separation and set-up of regulator. Some tariff reform and improvements in revenue collection. Some private sector involvement.

4 Separation of generation, transmission and distribution. Independent regulator set up. Rules for cost-reflective tariff-setting formulated and implemented. Substantial private sector involvement in distribution and/or generation. Some degree of liberalisation.

4+ Tariffs cost-reflective and provide adequate incentives for efficiency improvements. Largescale private sector involvement in the unbundled and well-regulated sector. Fully liberalised sector with well-functioning arrangements for network access and full competition in generation.

\section{Railways}


1 Monolithic structure operated as government department, with few commercial freedoms. No private sector involvement and extensive cross-subsidisation.

2 Rail operations distanced from state, but weak commercial objectives. Some business planning, but targets are general and tentative. No budgetary funding of public service obligations. Ancillary businesses separated, but little divestment. Minimal private sector involvement.

3 Commercial orientation in rail operations. Freight and passenger services separated and some ancillary businesses divested. Some budgetary compensation available for passenger services. Improved business planning with clear investment and rehabilitation targets, but funding unsecured. Some private sector involvement in rehabilitation and/or maintenance.

4 Railways fully commercialised, with separate internal profit centres for passenger and freight. Extensive market freedoms to set tariffs and investments. Implementation of medium-term business plans. Ancillary industries divested. Private sector participation in freight operation, ancillary services and track maintenance.

4+ Separation of infrastructure from operations and freight from passenger operations. Full divestment and transfer of asset ownership implemented or planned, including infrastructure and rolling stock. Rail regulator established and access pricing implemented.

\section{Roads}

1 Minimal degree of decentralisation and no commercialisation. All regulatory, road management and resource allocation functions centralised at ministerial level. New investments and road maintenance financing dependent on central budget allocations. Road user charges not based on the cost of road use. Road construction and maintenance undertaken by public construction units. No public consultation in the preparation of road projects.

2 Moderate degree of decentralisation and initial steps in commercialisation. Road/highway agency created. Improvements in resource allocation and public procurement. Road user charges based on vehicle and fuel taxes, but not linked to road use. Road fund established, but dependent on central budget. Road construction and maintenance undertaken primarily by corporatised public entities, with some private sector participation. Minimal public consultation/participation on road projects.

3 Fair degree of decentralisation and commercialisation. Regulation and resource allocation functions separated from road maintenance and operations. Level of vehicle and fuel taxes related to road use. Private companies able to provide and operate roads under negotiated commercial contracts. Private sector participation in road maintenance and/or through concessions to finance, operate and maintain parts of highway network. Limited public consultation/participation and accountability on road projects.

4 Large degree of decentralisation. Transparent methodology used to allocate road expenditures. Track record in competitive procurement for road design, construction, maintenance and operations. Large-scale private sector participation in construction, operations and maintenance directly and through public-private partnerships. Substantial public consultation/ participation and accountability on road projects.

4+ Fully decentralised road administration. Commercialised road maintenance operations competitively awarded to private companies. Road user charges reflect the full costs of road use and associated factors, such as congestion, accidents and pollution. Widespread private sector participation in all aspects of road provision. Full public consultation on new road projects.

\section{Telecommunications}

1 Little progress in commercialisation and regulation. Minimal private sector involvement and strong political interference in management decisions. Low tariffs, with extensive crosssubsidisation. Liberalisation not envisaged, even for mobile telephony and value-added services.

2 Modest progress in commercialisation. Corporatisation of dominant operator and some separation from public sector governance, but tariffs are still politically set.

3 Substantial progress in commercialisation and regulation. Telecommunications and postal services fully separated, and cross-subsidies reduced. Considerable liberalisation in the mobile segment and in value-added services. 
4 Complete commercialisation, including privatisation of the dominant operator, and comprehensive regulatory and institutional reforms. Extensive liberalisation of entry.

4+ Effective regulation through an independent entity. Coherent regulatory and institutional framework to deal with tariffs, interconnection rules, licensing, concession fees and spectrum allocation. Consumer ombudsman function.

\section{Water and waste water}

1 Minimal degree of decentralisation; no commercialisation. Services operated as vertically integrated natural monopolies by a government ministry or municipal departments. No financial autonomy and/or management capacity at municipal level. Low tariffs, low cash collection rates and high cross-subsidies.

2 Moderate degree of decentralisation; initial steps towards commercialisation. Services provided by municipally owned companies. Partial cost recovery through tariffs, and initial steps to reduce cross-subsidies. General public guidelines exist regarding tariff-setting and service quality but both under ministerial control. Some private sector participation through service or management contacts, or competition to provide ancillary services.

3 Fair degree of decentralisation and commercialisation. Water utilities operate with managerial and accounting independence from municipalities, using international accounting standards and management information systems. Operating costs recovered through tariffs, with a minimum level of cross-subsidies. More detailed rules drawn up in contract documents, specifying tariff review formulae and performance standards. Private sector participation through the full concession of a major service in at least one city.

4 Large degree of decentralisation and commercialisation. Water utilities managerially independent, with cash flows - net of municipal budget transfers - that ensure financial viability. No cross-subsidies. Semi-autonomous regulatory agency has power to advise and enforce tariffs and service quality. Substantial private sector participation through build-operator-transfer concessions, management contacts or asset sales in several cities.

4+ Water utilities fully decentralised and commercialised. Fully autonomous regulator exists with complete authority to review and enforce tariff levels and quality standards. Widespread private sector participation via service/ management/lease contracts. High-powered incentives, full concessions and/or divestiture of water and waste-water services in major urban areas. " 
Appendix G. Including EU preferential tariffs.

TABLE G1. Estimation with firm fixed effects using OLS productivities:

Productivity in domestic manufacturing firms and reform in upstream services sectors

\begin{tabular}{|c|c|c|c|c|c|c|c|}
\hline \multicolumn{2}{|c|}{ Dependent Variable: $\ln (\mathrm{TFP})$} & \multirow{3}{*}{$\begin{array}{c}\mathrm{I} \\
0.908 * * \\
(0.395)\end{array}$} & \multirow[t]{3}{*}{ II } & \multirow[t]{3}{*}{ III } & \multirow[t]{3}{*}{ IV } & \multirow[t]{3}{*}{$\mathrm{V}$} & \multirow[t]{3}{*}{ VI } \\
\hline Services input & EBRD & & & & & & \\
\hline linkages & & & & & & & \\
\hline & FDI (share) & & $5.900 * * *$ & & & & \\
\hline & & & $(1.903)$ & & & & \\
\hline & & & & $2.380 * *$ & & & \\
\hline & FDI (threshold) & & & $(0.953)$ & & & \\
\hline & Concentration & & & & -1.551 & & \\
\hline & & & & & $(3.025)$ & & \\
\hline & Privatization & & & & & $10.474 * *$ & \\
\hline & (share) & & & & & $(4.897)$ & \\
\hline & Privatization & & & & & & -22.735 \\
\hline & (threshold) & & & & & & $(19.944)$ \\
\hline \multirow{8}{*}{$\begin{array}{l}\text { Manufacturing } \\
\text { input linkages }\end{array}$} & FDI (share) & & -0.372 & & $-0.862 *$ & $-0.780 *$ & \\
\hline & & & $(0.473)$ & & $(0.484)$ & $(0.446)$ & \\
\hline & & -0.372 & & -0.403 & & & -0.555 \\
\hline & FDI (threshold) & $(0.408)$ & & $(0.399)$ & & & $(0.412)$ \\
\hline & MFN Tariff & -0.202 & $-0.413 * * *$ & $-0.302 * *$ & -0.215 & $-0.273 * *$ & -0.125 \\
\hline & & $(0.124)$ & $(0.149)$ & $(0.145)$ & $(0.131)$ & $(0.129)$ & $(0.119)$ \\
\hline & EU Tariff & 0.009 & 0.029 & 0.022 & 0.043 & 0.052 & 0.018 \\
\hline & & $(0.031)$ & $(0.029)$ & $(0.030)$ & $(0.034)$ & $(0.033)$ & $(0.033)$ \\
\hline \multirow{10}{*}{$\begin{array}{l}\text { Within sector } \\
\text { effects }\end{array}$} & FDI (share) & & 0.083 & & 0.337 & $0.331 *$ & \\
\hline & & & $(0.192)$ & & $(0.207)$ & $(0.189)$ & \\
\hline & & 0.227 & & 0.199 & & & $0.339 * *$ \\
\hline & FDI (threshold) & $(0.156)$ & & $(0.153)$ & & & $(0.160)$ \\
\hline & MFN Tariff & $0.109 *$ & $0.210 * * *$ & $0.153 * *$ & $0.120^{*}$ & $0.143 * *$ & 0.071 \\
\hline & & $(0.064)$ & $(0.077)$ & $(0.073)$ & $(0.069)$ & $(0.068)$ & $(0.062)$ \\
\hline & EU Tariff & -0.009 & -0.019 & -0.016 & $-0.027 *$ & $-0.029 *$ & -0.015 \\
\hline & & $(0.014)$ & $(0.013)$ & $(0.014)$ & $(0.016)$ & $(0.016)$ & $(0.015)$ \\
\hline & No. of obs. & 7155 & 7155 & 7155 & 7155 & 7155 & 7155 \\
\hline & $\mathrm{R}^{2}$ & 0.094 & 0.095 & 0.095 & 0.094 & 0.094 & 0.094 \\
\hline
\end{tabular}


TABLE G2. Estimation with firm fixed effects using Olley-Pakes productivities:

Productivity in domestic manufacturing firms and reform in upstream services sectors

\begin{tabular}{|c|c|c|c|c|c|c|c|}
\hline \multicolumn{2}{|c|}{ Dependent Variable: $\ln (\mathrm{TFP})$} & \multirow{3}{*}{$\begin{array}{c}\text { II } \\
0.725^{*} \\
(0.424)\end{array}$} & \multirow[t]{2}{*}{ III } & \multirow[t]{2}{*}{ IV } & \multirow[t]{2}{*}{ V } & \multirow[t]{2}{*}{ VII } & \multirow[t]{2}{*}{ VIII } \\
\hline Services input & EBRD & & & & & & \\
\hline \multirow[t]{11}{*}{ linkages } & & & & & & & \\
\hline & FDI (share) & & $5.390 * * *$ & & & & \\
\hline & & & $(1.963)$ & & & & \\
\hline & & & & $1.948^{*}$ & & & \\
\hline & FDI (threshold) & & & $(0.996)$ & & & \\
\hline & Concentration & & & & -1.113 & & \\
\hline & & & & & $(3.053)$ & & \\
\hline & Privatization & & & & & $12.117 * *$ & \\
\hline & (share) & & & & & $(4.616)$ & \\
\hline & Privatization & & & & & & -11.73 \\
\hline & (threshold) & & & & & & $(19.038)$ \\
\hline \multirow{8}{*}{$\begin{array}{l}\text { Manufacturing } \\
\text { input linkages }\end{array}$} & FDI (share) & & -0.057 & & -0.523 & -0.386 & \\
\hline & & & $(0.490)$ & & $(0.516)$ & $(0.459)$ & \\
\hline & & -0.203 & & -0.224 & & & -0.354 \\
\hline & FDI (threshold) & $(0.444)$ & & $(0.429)$ & & & $(0.437)$ \\
\hline & MFN Tariff & -0.166 & $-0.362 * *$ & $-0.248^{*}$ & -0.18 & $-0.248 * *$ & -0.106 \\
\hline & & $(0.116)$ & $(0.146)$ & $(0.140)$ & $(0.125)$ & $(0.124)$ & $(0.114)$ \\
\hline & EU Tariff & 0.013 & 0.031 & 0.023 & 0.043 & $0.056^{*}$ & 0.022 \\
\hline & & $(0.032)$ & $(0.029)$ & $(0.031)$ & $(0.034)$ & $(0.033)$ & $(0.032)$ \\
\hline \multirow{10}{*}{$\begin{array}{l}\text { Within sector } \\
\text { effects }\end{array}$} & FDI (share) & & -0.088 & & 0.153 & 0.126 & \\
\hline & & & $(0.198)$ & & $(0.217)$ & $(0.193)$ & \\
\hline & & 0.156 & & 0.131 & & & 0.248 \\
\hline & FDI (threshold) & $(0.162)$ & & $(0.156)$ & & & $(0.162)$ \\
\hline & MFN Tariff & 0.098 & $0.192 * *$ & $0.135^{*}$ & $0.110^{*}$ & $0.137 * *$ & 0.069 \\
\hline & & $(0.060)$ & $(0.075)$ & $(0.071)$ & $(0.065)$ & $(0.065)$ & $(0.060)$ \\
\hline & EU Tariff & -0.015 & $-0.025^{*}$ & -0.021 & $-0.032 *$ & $-0.034 * *$ & -0.021 \\
\hline & & $(0.015)$ & $(0.013)$ & $(0.015)$ & $(0.016)$ & $(0.016)$ & $(0.015)$ \\
\hline & No. of obs. & 7155 & 7155 & 7155 & 7155 & 7155 & 7155 \\
\hline & $\mathrm{R}^{2}$ & 0.093 & 0.093 & 0.093 & 0.092 & 0.093 & 0.092 \\
\hline
\end{tabular}


Appendix H. Summary statistics.

Table H1. Summary statistics.

\begin{tabular}{|c|c|c|c|c|}
\hline & & Obs & Mean & Std. Dev \\
\hline \multirow[t]{6}{*}{ Firm specific variables } & $\ln$ (output) & 7155 & 6.96 & 1.26 \\
\hline & $\ln ($ capital) & 7155 & 5.22 & 1.99 \\
\hline & $\ln ($ labor cost) & 7155 & 4.94 & 1.24 \\
\hline & $\ln ($ material and service inputs) & 7155 & 6.20 & 1.60 \\
\hline & $\ln ($ OLS TFP) & 7155 & 2.01 & 0.61 \\
\hline & $\ln ($ Olley-Pakes TFP) & 7155 & 2.15 & 0.78 \\
\hline \multirow{6}{*}{$\begin{array}{l}\text { Services input } \\
\text { linkages }\end{array}$} & EBRD & 7155 & 0.43 & 0.10 \\
\hline & FDI (share) & 7155 & 0.02 & 0.01 \\
\hline & FDI (threshold) & 7155 & 0.03 & 0.01 \\
\hline & Concentration & 7155 & 0.06 & 0.01 \\
\hline & Privatization (share) & 7155 & 0.02 & 0.01 \\
\hline & Privatization (threshold) & 7155 & 0.02 & 0.01 \\
\hline \multirow{4}{*}{$\begin{array}{l}\text { Manufacturing } \\
\text { input linkages }\end{array}$} & FDI (share) & 7155 & 0.13 & 0.07 \\
\hline & FDI (threshold) & 7155 & 0.18 & 0.08 \\
\hline & MFN tariff & 7155 & 4.41 & 1.31 \\
\hline & EU tariff & 7155 & 1.08 & 1.61 \\
\hline \multirow{4}{*}{$\begin{array}{l}\text { Within sector } \\
\text { effects }\end{array}$} & FDI (share) & 7155 & 0.17 & 0.13 \\
\hline & FDI (threshold) & 7155 & 0.21 & 0.15 \\
\hline & MFN Tariff & 7155 & 5.83 & 2.58 \\
\hline & EU tariff & 7155 & 1.71 & 3.09 \\
\hline
\end{tabular}


Figures

FIGURE 1. FDI Inflows into the Czech Republic 1998-2002 (in Millions of Euros)

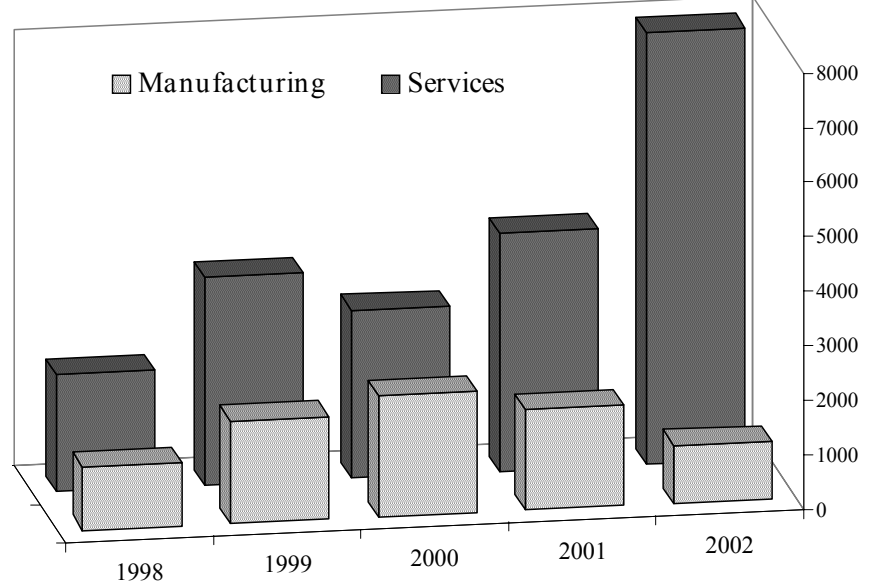

Source: Czech National Bank

FIGURE 2. Distribution of FDI Inflows over Services Sectors (cumulative inflows 1998-2002)

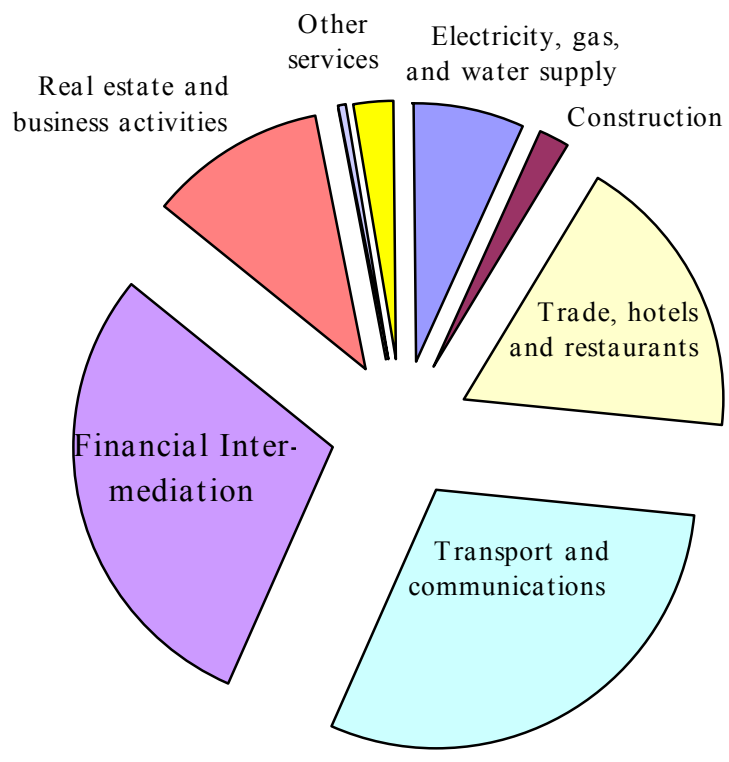

Source: Czech National Bank 
FIGURE 3. Cellular Phones and Internet Usage. Czech Republic vs. Western European Countries

Cellular Phones per 100 Inhabitants

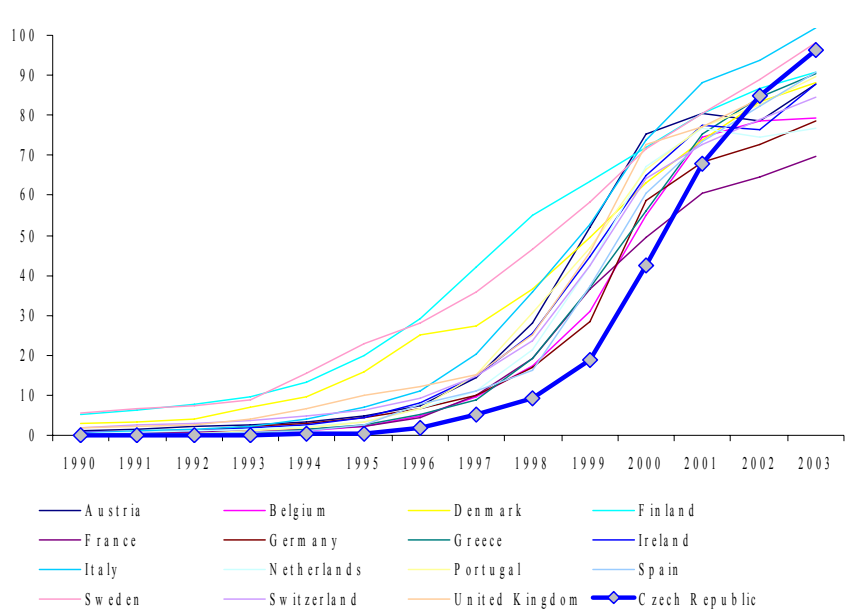

Source: ITU
Internet Users per 100 Inhabitants

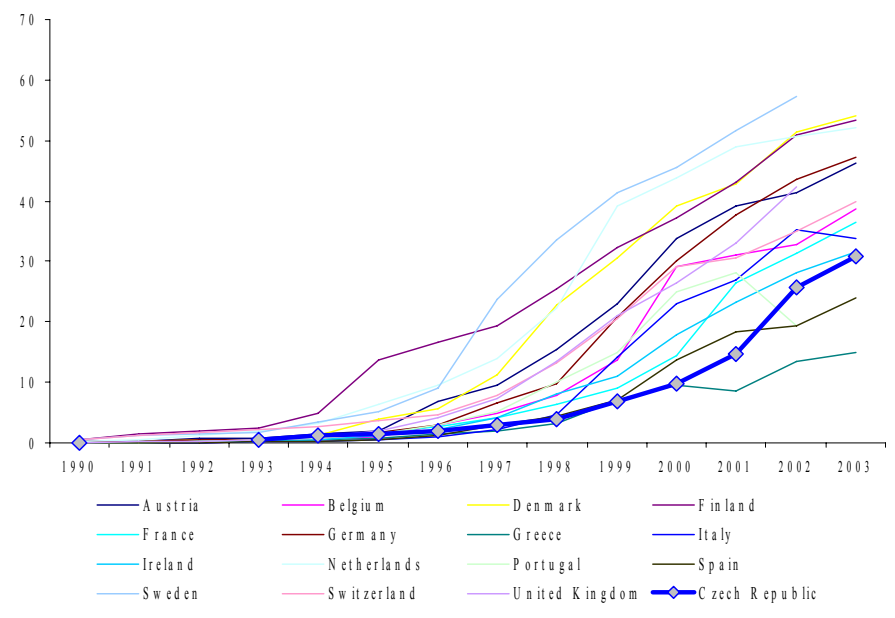


FIGURE 4. Firm Perceptions about Services Reforms in the Czech Republic: Survey Results.

Perceived Impact of Liberalization of Telecommunications Sector on

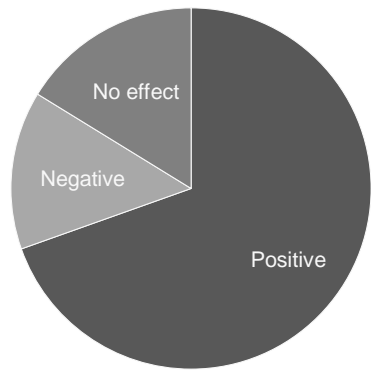

Prices

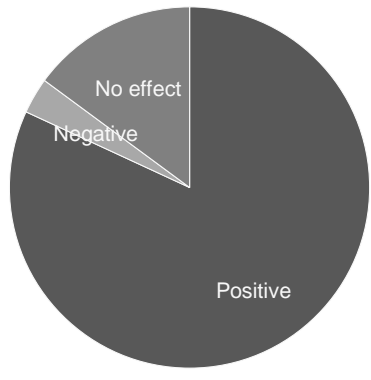

Quality

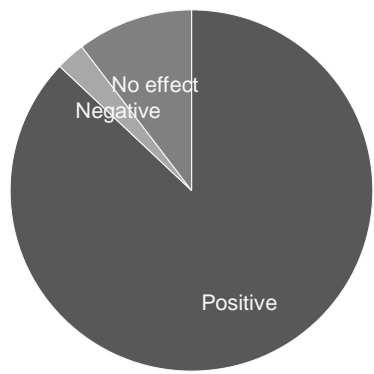

Range of Services Offered

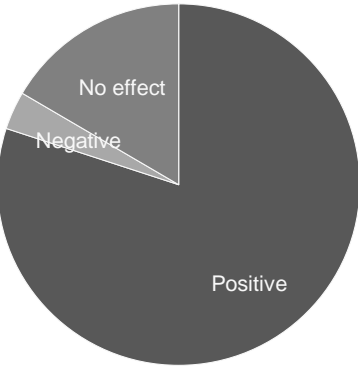

Range of Services Offered

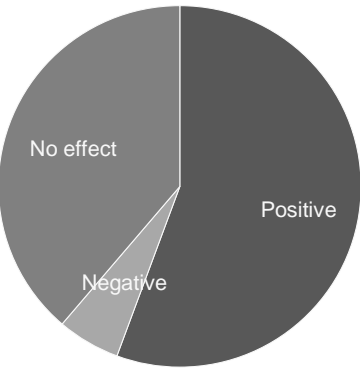

Range of Services Offered

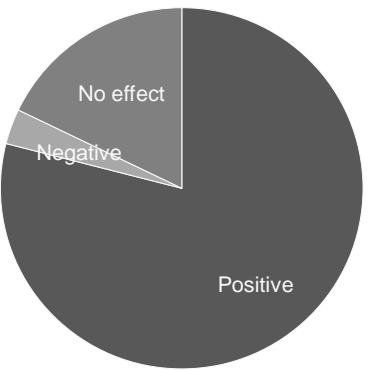

Range of Services Offered

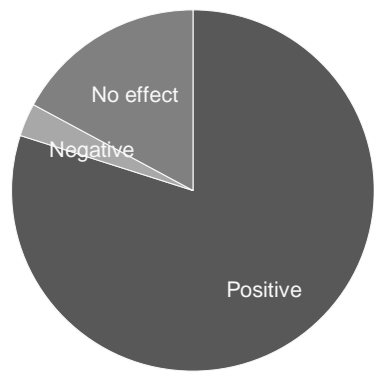

Availability of Services

Perceived Impact of Liberalization of Banking Sector on

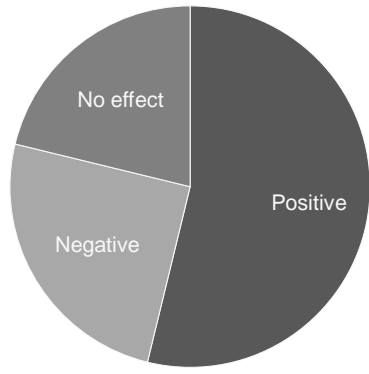

Prices

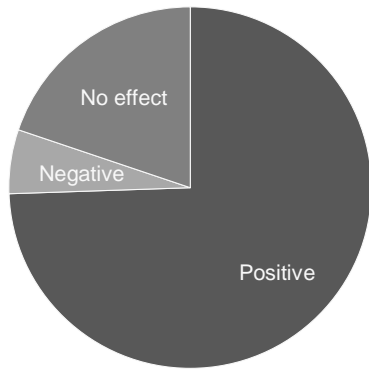

Quality

Perceived Impact of Liberalization of Accounting Sector on

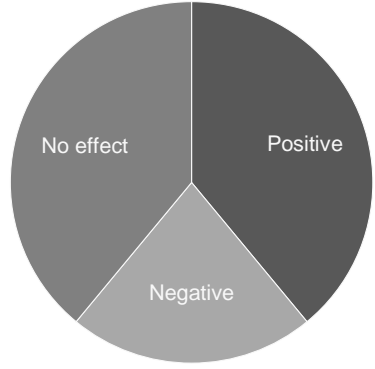

Prices

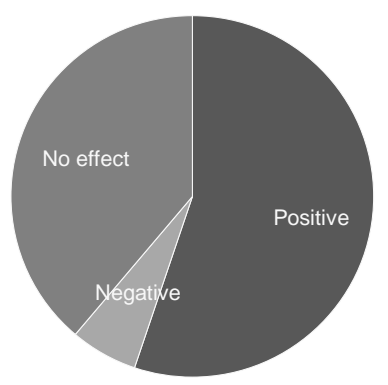

Quality

Perceived Impact of Liberalization of Insurance Sector on

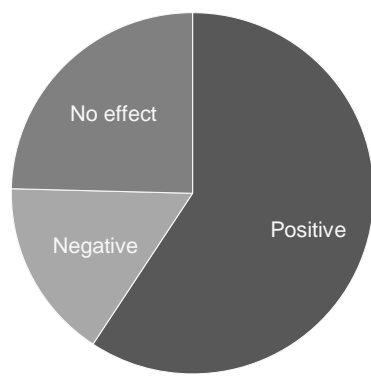

Prices

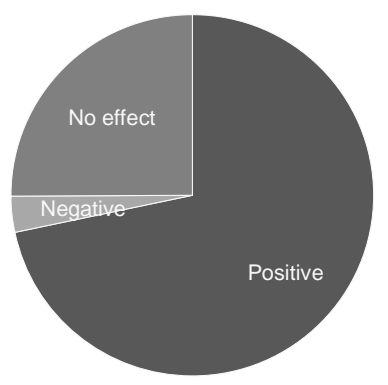

Quality

Perceived Impact of Liberalization of Transport Sector on

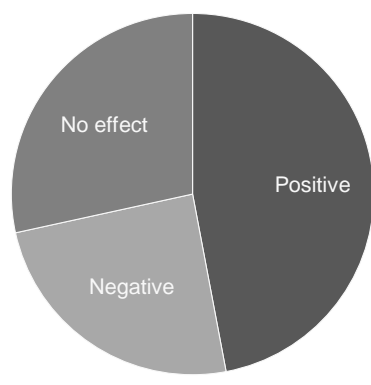

Prices

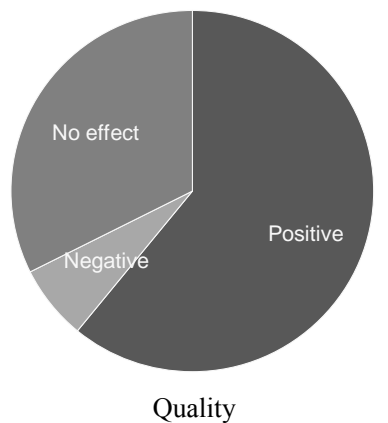

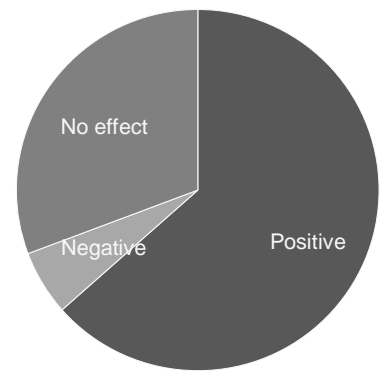

Range of Services Offered

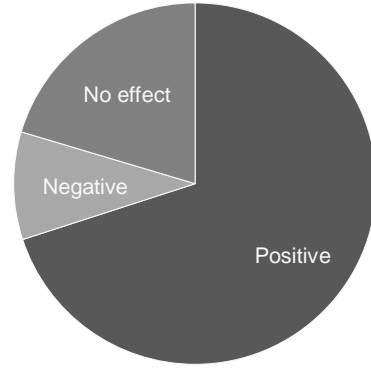

Availability of Services

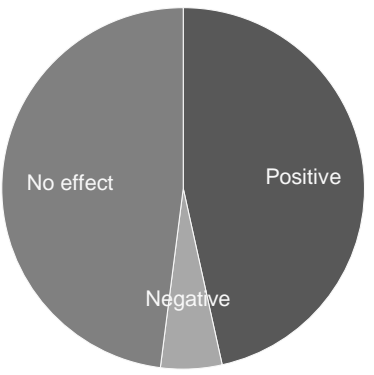

Availability of Services

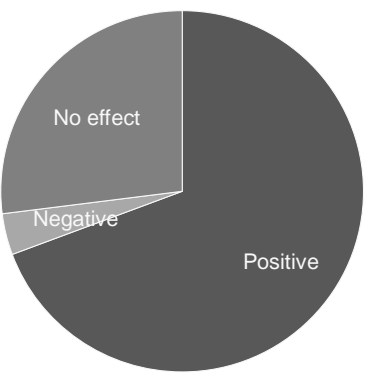

Availability of Services

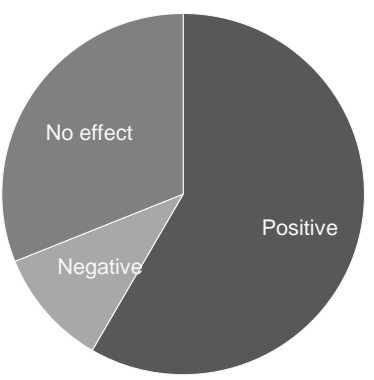

Availability of Services 